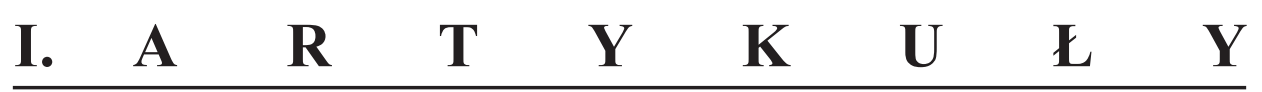

DOI: $10.19195 / 0080-3626.60 .2$

JADWIGA KONIECZNA

\title{
UDZIAŁ AKADEMICKIEGO BIBLIOTEKOZNAWSTWA W ROZWOJU BIBLIOLOGII I INFORMATOLOGII W POLSCE W LATACH 1945-2015
}

Geneza i rozwój uczelnianych ośrodków kształcenia bibliotekarzy, dzieje poszczególnych ośrodków — zakładów, katedr, instytutów. Badania naukowe realizowane w polskich uczelniach, kierunki i zmiany zachodzące w ich tematyce, nazwiska wybranych badaczy i tytuły ich znaczących prac.

SŁOWA KLUCZOWE: bibliologia — badania, informatologia — badania, akademickie ośrodki bibliotekoznawcze - historia

Musiało minąć ponad 130 lat, licząc od pierwszych wykładów z bibliografii Jerzego Samuela Bandtkiego na Uniwersytecie Krakowskim (1811), aby studia bibliotekoznawcze stały się w Polsce pełnoprawnym kierunkiem uniwersyteckim. Zorganizowanie w roku 1945, na nowo otwartym Uniwersytecie Łódzkim, Studium Bibliotekoznawczego nie było jednak wynikiem przypadku. Był to z jednej strony efekt rozwijających się przez cały wiek XIX i pierwszą połowę XX wieku badań w obrębie szeroko pojętej bibliologii (chociaż zazwyczaj pod innymi określeniami), a z drugiej - ówczesnych uwarunkowań społeczno-politycznych i kulturowych. Oto w ramach budowy nowego ustroju w dużym robotniczym mieście powstawał uniwersytet, na którym łatwiej można było realizować politykę wprowadzania nieuznawanych dotychczas przez „stare” uniwersytety umiejętności praktycznych. Nowy uniwersytet miał bowiem, w założeniu władz, przede wszystkim kształcić kadry przydatne w budowaniu socjalistycznej gospodarki i kultury. W takiej sytuacji wiosną 1945 roku na Wydziale Pracy Kulturalnej profesor Jan Muszkowski rozpoczął zajęcia z bibliotekoznawstwa. Natomiast oficjalne powołanie, lecz już na Wydziale Humanistycznym, Katedry Bibliotekoznawstwa i nominacja J. Muszkowskiego na jej kierownika nastąpiły 11 lutego 1946 roku ${ }^{1}$.

${ }^{1}$ Helena WIĘCKOWSKA, Pierwsza w Polsce Katedra Bibliotekoznawstwa, Przegląd Biblioteczny (37) 1969, z. 2/3, s. 114-134. 
W ten sposób została zapoczątkowana baza instytucjonalna do dalszego organizowania i rozwijania badań naukowych w zakresie nauki o książce. Jej późniejszy rozwój następował w ślad za pojawianiem się kolejnych ośrodków akademickiego kształcenia bibliotekarzy. Niezależnie od prowadzenia działalności dydaktycznej zatrudnieni w tych placówkach pracownicy naukowo-dydaktyczni systematycznie realizowali badania w obszarze szeroko pojętej bibliologii, przyczyniając się w ten sposób do ukształtowania dyscypliny, której jeszcze w początkach lat 50. XX wieku często odmawiano naukowości²

Celem niniejszego opracowania jest przypomnienie nie tylko głównych faktów i zjawisk towarzyszących tworzeniu w poszczególnych uczelniach jednostek naukowo-badawczych o profilu bibliotekoznawczym (katedr, zakładów, instytutów), lecz przede wszystkim zaprezentowanie ich udziału w rozwijaniu polskiej bibliologii w ciągu minionych 70 lat, chociaż należy pamiętać, że w rozwoju nauki o książce, zwłaszcza w latach 50. i 60., znaczącą rolę odegrały także biblioteki naukowe i inne placówki naukowo-badawcze ${ }^{3}$. Jednak ze względu na obchodzony w 2015 roku jubileusz siedemdziesięciolecia akademickiego kształcenia bibliotekarzy $^{4}$ oraz z racji braku w literaturze przedmiotu opracowania prezentującego całościowy obraz instytucjonalnego i naukowego rozwoju uczelnianych ośrodków bibliotekoznawczych, ich osiągnięć i porażek, zdecydowano się podjąć próbę takiego opisu 5 .

Ponieważ w omawianym okresie w systemie akademickiego kształcenia bibliotekarzy zachodziły liczne zmiany i przekształcenia, zagadnienia omówione w części pierwszej artykułu zostaną przedstawione w ujęciu diachronicznym, z wyodrębnieniem trzech etapów: 1945-1974, 1975-1989 i 1990-2015. Wybór jako cezury czasowej roku 1975 podyktowany był istotnymi przemianami, jakie nastąpiły wówczas w organizacji kształcenia bibliotekarzy na poziomie wyższym. Od roku akademickiego 1975/1976 weszły bowiem w życie nowe, ujednolicone

${ }^{2}$ Np. Władysław BIEŃKOWSKI, O pseudonauce bibliologii i o najpilniejszych potrzebach bibliografii, Warszawa: Związek Bibliotekarzy i Archiwistów Polskich 1953; Tadeusz MARGUL, Z obłoków bibliologii na ziemię bibliotekarstwa, Przegląd Biblioteczny (21) 1953, z. 4, s. 342-358.

3 Zob. H. WIĘCKOWSKA, Organizacja, stan i kierunki badań bibliologicznych 1945-1967, [w:] Księga VI Zjazdu Bibliotekarzy Polskich 12-14 II 1968. Pod red. Jadwigi Kołodziejskiej, Warszawa: SBP 1969, s. 45-77.

${ }^{4}$ Z tej okazji Katedra Bibliotekoznawstwa i Informacji Naukowej Uniwersytetu Łodzkiego zorganizowała konferencję zatytułowaną Ewolucja akademickiego kształcenia bibliotekarzy w latach 1945-2015. Materiały z konferencji ukazały się drukiem w końcu 2016 r. - Uniwersyteckie kształcenie bibliotekarzy. W 70-lecie studiów bibliotekoznawczych i informacyjnych na Uniwersytecie Łódzkim. Praca zbiorowa pod red. Jadwigi Koniecznej i Stanisławy Kurek-Kokocińskiej, Łódź: Wydawnictwo UŁ 2016.

5 Stosunkowo liczne są natomiast opracowania poświęcone historii poszczególnych ośrodków - ich osiągnięć organizacyjnych, dydaktycznych i naukowych — publikowane zazwyczaj z okazji kolejnych jubileuszy tych placówek. Zawarte w nich dane zostały wykorzystane w niniejszym opracowaniu, o czym informują przypisy. 
programy kształcenia, a jednocześnie zwiększyła się liczba uczelni prowadzących studia bibliotekoznawcze. Rok 1990 zapoczątkował natomiast procesy transformacji ustrojowej, która znacząco wpłynęła na system szkolnictwa wyższego, a tym samym na rozwój ośrodków bibliotekoznawczych. Oczywiście prezentowane w ten sposób zjawiska i procesy niejednokrotnie wykraczają poza ramy czasowe, w których zostały umieszczone. Jest to jednak typowa niedoskonałość wszelkich „podziałów” z zastosowaniem kryterium chronologicznego, które w tym przypadku okazało się jednak niezbędne.

Z kolei w części drugiej, poświęconej kierunkom badań realizowanych w środowisku akademickiego bibliotekoznawstwa, przyjęto układ instytucjonalny, chronologię traktując jedynie jako element wtórny, porządkujący informacje o prowadzonych w poszczególnych placówkach badaniach. Dostrzegalna w tym obrazie pewna nierównomierność w doborze i prezentacji materiału, zwłaszcza w odniesieniu do kierunków badań i dorobku naukowego ostatniego dziesięciopiętnastolecia, wynika głównie z braku niezbędnej perspektywy czasowej i dostatecznej szansy na sformułowanie dla tego okresu generalizujących ocen. Ponieważ jednak zjawiskiem powszechnym stało się obecnie zamieszczanie w sieci informacji bibliograficznych o dorobku poszczególnych pracowników lub całych jednostek, prezentację ich osiągnięć w III RP ograniczono do najbardziej podstawowych informacji.

\section{BAZA INSTYTUCJONALNA}

\subsection{LATA 1945-1974}

Akademickie ośrodki bibliotekoznawcze, mimo pomyślnego startu, nieprędko zwiększyły swą obecność na polskich uczelniach. Do połowy lat 70. tylko w trzech uniwersytetach zaistniały placówki kształcące magistrów bibliotekoznawstwa. Po katedrze na Uniwersytecie Łódzkim następną powołano w końcu 1951 roku na Uniwersytecie Warszawskim ${ }^{6}$, a jej kierownikiem mianowano prof. Aleksandra Birkenmajera. W roku 1956 z inicjatywy prof. Antoniego Knota na Uniwersytecie Wrocławskim działalność rozpoczęła Katedra Bibliotekoznawstwa, której kierownikiem został dr Karol Głombiowski ${ }^{7}$.

Rozwój tych trzech ośrodków przebiegał odmiennie. W najmniej korzystnej sytuacji znalazła się katedra na Uniwersytecie Łódzkim, która po przedwczesnej śmierci J. Muszkowskiego, w 1953 roku, nie uzyskała prawa do rekrutacji

${ }^{6}$ Rozporządzenie Ministra Szkół Wyższych i Nauki z dnia 6 października 1951 r. w sprawie zmian organizacyjnych na Uniwersytecie Warszawskim, Dziennik Ustaw $1951 \mathrm{Nr} 52$, poz. 370.

${ }^{7}$ Krzysztof MIGOŃ, Pół wieku Instytutu Informacji naukowej i Bibliotekoznawstwa Uniwersytetu Wrocławskiego (1956-2006), [w:] Dokument, ksiażka i biblioteka w badaniach naukowych i nauczaniu uniwersyteckim. Pod red. Marty Skalskiej-Zlat i Anny Żbikowskiej-Migoń, Wrocław: Wydaw. Uniwersytetu Wrocławskiego 2008, s. 169-179. 
studentów, co poważnie zahamowało na wiele lat tworzenie w Łodzi naukowego środowiska bibliotekoznawczego. Niektóre z zatrudnionych tutaj osób (m.in. Anna Czekajewska-Jędrusik i Zdzisława Brzozowska) przeniosły się do katedry na Uniwersytecie Warszawskim i tam rozwijały swoją karierę naukową. Jedynym w zasadzie pracownikiem łódzkiej katedry (aż do roku 1969) była Helena Więckowska, która po śmierci Muszkowskiego przejęła jej kierownictwo, łącząc tę funkcję ze stanowiskiem dyrektora Biblioteki Uniwersytetu Łódzkiego. Stanowiska te łączył również następca H. Więckowskiej, kolejny kierownik łódzkiej katedry - Bolesław Świderski.

Podobnych problemów nie miała Katedra na Uniwersytecie Warszawskim, chociaż i tutaj rozwój własnej kadry następował powoli, w związku z czym np. w prowadzeniu zajęć korzystano z pomocy bibliotekarzy z Biblioteki Uniwersytetu Warszawskiego, Biblioteki Narodowej i innych placówek. Z czasem, w wyniku zatrudniania kolejnych asystentów, m.in. A. Czekajewskiej-Jędrusik, Aleksandry Niemczykowej oraz samodzielnych pracowników nauki — docentów Krystyny Remerowej i Ksawerego Świerkowskiego, sytuacja na tym polu wyraźnie się poprawiła. Rozwój organizacyjny i personalny Katedry, połączony ze stopniową reorientacją badań naukowych w kierunku informacji naukowej został usankcjonowany jej przekształceniem w czerwcu 1968 roku w Instytut Bibliotekoznawstwa i Informacji Naukowej (IBiIN) oraz zmianą jego usytuowania w strukturach Uniwersytetu: przeniesiono go z Wydziału Filologicznego na Wydział Historyczny ${ }^{8}$.

Z perspektywy czasu można ocenić, że najbardziej korzystnie przebiegał rozwój Katedry na Uniwersytecie Wrocławskim, która wysunęła się wkrótce na czoło ośrodków bibliotekoznawczych. Jeszcze przed jej formalnym utworzeniem ważną inicjatywą na rzecz zinstytucjonalizowania badań na polu bibliotekoznawstwa było powołanie w 1953 roku (za sprawą A. Knota), w ramach Wrocławskiego Towarzystwa Naukowego, Komisji Bibliografii i Bibliotekoznawstwa, która stała się forum prezentacji prowadzonych prac badawczych. Utworzenie więc w 1956 roku na Wydziale Filologicznym Katedry Bibliotekoznawstwa było w pewnym stopniu naturalną konsekwencją prowadzonych w środowisku wrocławskim, niejednokrotnie już zaawansowanych, badań o charakterze bibliologicznym, a powołanie na stanowisko kierownika K. Głombiowskiego, byłego pracownika Biblioteki Uniwersyteckiej, stwarzało szansę na właściwy rozwój nowej placówki ${ }^{9}$. Zgodnie z ogólnokrajowymi przekształceniami w nauce akademickiej nadano jej w 1969 roku status Instytutu Bibliotekoznawstwa, a jednocześnie stopniowo poszerzano

8 Anna RADZIEJOWSK A-HILCHEN, Historia Instytutu Informacji Naukowej i Studiów Bibliologicznych Uniwersytetu Warszawskiego, [w:] Warszawskie uniwersyteckie studia bibliotekoznawcze i informacyjne (1951-2001). Praca zbiorowa opracowana przez zespół pod przewodnictwem Elżbiety Barbary Zybert, Warszawa: Instytut Informacji Naukowej i Studiów Bibliologicznych Uniwersytetu Warszawskiego 2002, s. 81-84.

9 K. MIGOŃ, op. cit., s. 172. 
(w latach 60. i 70.) kadrę naukową o absolwentów własnych studiów bibliotekoznawczych.

Rozwój naukowy młodszych pracowników nauki postępował w pierwszych latach istnienia uniwersyteckich katedr bibliotekoznawczych stosunkowo wolno. Wśród zatrudnionej w tych ośrodkach akademickich kadry naukowej niewielu było etatowych asystentów, nie mówiąc o adiunktach. Większość zajęć, z wyjątkiem kierowników jednostek, prowadzili w ramach godzin zleconych pracownicy uczelnianych bibliotek czy innych instytucji książki. Obciążeni pracą na dwóch etatach niewiele czasu mogli poświęcić na pracę stricte naukową, a ponadto tylko nieliczni mieli wykształcenie bibliotekoznawcze. $Z$ czasem jednak ten obraz zaczął się korzystnie zmieniać, czego świadectwem była rosnąca liczba doktoratów obronionych w trzech katedrach bibliotekoznawstwa w latach 60 . XX wieku ${ }^{10}$.

Swoistym dowodem na ukształtowanie się środowiska naukowego polskich bibliologów było też powołanie w roku 1970 Międzyuczelnianych Zeszytów Naukowych Resortu Nauki, Szkolnictwa Wyższego i Techniki pt. „Studia o Książce”. Rocznik ten, wydawany przez Wydawnictwo Zakładu Narodowego im. Ossolińskich, szybko stał się ważnym forum publikacyjnym dla pracowników naukowych $\mathrm{z}$ istniejących ośrodków akademickich bibliotekoznawstwa ${ }^{11}$. Podobną rolę odgrywały wychodzące od 1957 roku, także we Wrocławiu, „Roczniki Biblioteczne”, co prawda formalnie będące organem naukowym bibliotek szkół wyższych. Oczywiście obok pracowników katedr i instytutów bibliotekoznawstwa w obu tych periodykach publikowali swoje prace także bibliotekarze $\mathrm{z}$ bibliotek naukowych ${ }^{12}$.

Przełom lat 60. i 70. XX wieku przyniósł pierwsze zwiastuny zwiększenia liczby ośrodków bibliotekoznawczych, co było związane z rozwojem akademickiego kształcenia bibliotekarzy. Nową jego formą były czterosemestralne międzywydziałowe studia bibliotekoznawstwa. Pierwsze powołano w roku akademickim 1966/1967 na Uniwersytecie Adama Mickiewicza w Poznaniu, a następne na Uniwersytecie Łódzkim (1969/1970) i Uniwersytecie Jagiellońskim (1970/1971). Studia międzywydziałowe przeznaczone były dla słuchaczy kierunków humanistycznych (historii, filologii polskiej) i postrzegane, z jednej strony, jako możliwość przygotowania dwukierunkowo wykształconych bibliotekarzy, a z drugiej,

10 Wykaz prac doktorskich i magisterskich wykonanych $w$ katedrach bibliotekoznawstwa w latach 1950-1961, Roczniki Biblioteczne (6) 1962, z. 1/2, s. 264-272. Pierwszym doktoratem z bibliotekoznawstwa był obroniony w 1952 na Uniwersytecie Łódzkim doktorat K. Głombiowskiego.

11 Zob. Małgorzata KORCZYŃSKA-DERKACZ, Agnieszka ŁUSZPAK, ,,Studia o Ksiażzce" (1970-1993) - koncepcje programowe i ich realizacja, artykuł publikowany w niniejszym tomie.

12 Anna ŻBIKOWSKA-MIGOŃ, ,Roczniki Biblioteczne”- pismo bibliotek i o bibliotekach: przemiany profilu i zbiorowości autorów (1957-2010), [w:] Czasopisma naukowe bibliotek, archiwów, muzeów. Pod red. Agnieszki Królczyk, Kórnik: Biblioteka Kórnicka PAN 2010, s. $139-152$. 
jako dające absolwentom tych kierunków szansę na podjęcie pracy poza szkolnictwem $^{13}$. Niestety, forma ta $\mathrm{z}$ różnych przyczyn nie sprawdziła się i zaniechano jej kontynuacji. Natomiast sukcesem okazały się zainaugurowane w 1968 roku w Poznaniu studia podyplomowe.

Próbując zwiększać liczbę profesjonalnych kadr bibliotekarskich, poczęto do systemu instytucji ich kształcących włączać także wyższe szkoły pedagogiczne i/lub wyższe szkoły nauczycielskie, tworząc w nich nowy kierunek zawodowy - filologia polska z bibliotekoznawstwem. Studia takie prowadzono krócej lub dłużej w: Kielcach (od 1970/1971), Bydgoszczy (od 1971/1972), Poznaniu (od 1971/1972), w Wyższej Szkole Pedagogicznej w Krakowie (od 1971/1972), Olsztynie (od 1974/1975), Rzeszowie (od 1971/1972), Szczecinie (od 1975/1976), Zielonej Górze (od 1975/1976) i Katowicach (od 1959) ${ }^{14}$. Rozwój dydaktyki powodował, że w uczelniach tych $\mathrm{z}$ biegiem lat tworzono komórki organizacyjne w postaci zakładów bibliotekoznawstwa, jednak potencjał naukowy większości z nich był stosunkowo niewielki.

\subsection{LATA $1975-1989$}

Przełomowe dla organizacji systemu bibliotekoznawstwa akademickiego okazały się lata 1974-1975. Pod wpływem zmian zachodzących w szkolnictwie bibliotekarskim w krajach zachodnich, co znajdowało wyraz również w działaniach IFLA, na zlecenie Ministerstwa Nauki Szkolnictwa Wyższego i Techniki kilkunastoosobowy Zespół Dydaktyczny opracował nowy program akademickiego kształcenia bibliotekarzy dla czteroletniego cyklu magisterskiego. Ze względu na odmienności programów realizowanych dotychczas w dwóch największych ośrodkach, czyli uniwersytetach Warszawskim i Wrocławskim, nowy program opracowano w dwóch wariantach. Odpowiadający dotychczasowemu kierunkowi księgoznawczemu nazwano profilem humanistycznym, a eksponujący bibliotekoznawstwo i informację naukową — profilem matematycznym. Nowe, ujednolicone programy zaczęły obowiązywać od roku akademickiego 1975/1976 w zwiększonej liczbie ośrodków - w dziewięciu uniwersytetach (tj. wszystkich z wyjątkiem Katolickiego Uniwersytetu Lubelskiego) i pięciu wyższych szkołach pedagogicznych. Profil matematyczny przyjęły uniwersytety: Jagielloński, Poznański i Warszawski, pozostałe uniwersytety oraz wyższe szkoły pedagogiczne realizowały profil humanistyczny ${ }^{15}$.

Tak radykalne mery toryczne i ilościowe zmiany w dotychczasowym systemie kształcenia oprócz efektów pozytywnych przyniosły też wiele problemów. Było

13 Stanisław KUBIAK, Kształcenie bibliotekarzy i pracowników informacji naukowej na poziomie wyższym, Przegląd Biblioteczny (44) 1976, z. 4, s. 395-415.

${ }^{14}$ H. WIĘCKOWSKA, Akademickie kształcenie bibliotekarzy. Zarys historyczny, Warszawa: SBP 1979, s. 52, 63; S. KUBIAK, op. cit., s. 403.

15 H. WIĘCKOWSKA, Akademickie kształcenie bibliotekarzy..., s. 43-52. 
to szczególnie widoczne w nowo powstałych ośrodkach, w których brakowało lokali, pomocy naukowych i stabilnej, profesjonalnej kadry. Ogólnie odczuwano brak podręczników i skryptów - część istniejących zawierała treści nieaktualne lub niedostosowane do kształcenia uniwersyteckiego, a nakłady innych były już dawno wyczerpane. Apelowano więc do środowisk akademickich o przygotowywanie opracowań monograficznych i syntetycznych, które nie tylko przekazywałyby stosowną wiedzę, lecz także wskazywały nowe możliwości badawcze ${ }^{16}$.

Najdotkliwsze były jednak problemy kadrowe. Wśród zatrudnionych nauczycieli przeważały osoby pracujące na tzw. godzinach zleconych. W roku akademickim 1977/1978 w 14 uczelniach prowadzących różne formy kształcenia bibliotekarzy na pełnych etatach pracowało 131 osób (w tym 20 profesorów i docentów, 45 adiunktów i starszych wykładowców oraz 66 asystentów), 22 nauczycieli zatrudnionych było na pół etatu, a na godzinach zleconych - 189 osób. Ponad połowa (66 osób) pełnozatrudnionych pracowała w trzech uniwersytetach: we Wrocławiu (24), w Poznaniu (23) i w Warszawie (19) ${ }^{17}$.

Jednak w miarę upływu lat kadry pracowników naukowo-dydaktycznych powiększały się o młodych magistrów bibliotekoznawstwa, a później także bibliotekoznawstwa i informacji naukowej. Rosła liczba przeprowadzanych corocznie przewodów doktorskich. Początkowo głównie w uniwersytetach Wrocławskim, Warszawskim i Łódzkim, lecz pod koniec lat 70. pierwsze doktoraty miały miejsce także na Uniwersytecie Jagiellońskim (Zakład Bibliotekoznawstwa powstał tam w roku 1974). Tylko w latach 1975-1980 blisko 40 osób uzyskało stopień naukowy doktora ${ }^{18}$, a w następnej dekadzie liczba ta znacznie się powiększyła.

Niestety, możliwości publikowania dokonań naukowych były mocno ograniczone. Poza istniejącymi już periodykami o charakterze bibliologicznym, które zresztą ukazywały się niejednokrotnie z dużym opóźnieniem w stosunku do założeń redakcyjnych, powstało niewiele nowych czasopism. Przyczyną były trudności finansowe, brak papieru, niewydolna baza poligraficzna oraz cenzura. Jedynie Instytut Bibliotekoznawstwa i Informacji Naukowej UW z inicjatywy Barbary Bieńkowskiej rozpoczął w 1975 roku wydawanie wydawnictwa ciągłego, prezentującego wyniki badań księgoznawczych, zatytułowanego „Z Badań nad Polskimi Księgozbiorami Historycznymi”. W latach 1982-1988 Zakład Bibliotekoznawstwa Wyższej Szkoły Pedagogicznej w Krakowie opublikował w ramach „Rocznika Naukowo-Dydaktycznego Wyższej Szkoły Pedagogicznej im. Komisji Edukacji Narodowej” dziewięć zeszytów serii „Prace Bibliotekoznawcze”. Wszystkie

16 S. KUBIAK, op. cit., s. 406-407.

17 H. WIĘCKOWSKA, Akademickie kształcenie bibliotekarzy..., s. 58-59.

18 Obliczenia na podstawie Wykazów prac doktorskich i magisterskich wykonanych $w$ Instytutach Bibliotekoznawstwa, a publikowanych w „Rocznikach Bibliotecznych” w latach 1975-1980 oraz Spisów prac magisterskich i doktorskich z zakresu nauki o książe, informacji naukowej i czasopiśmiennictwa wykonanych w Ut, autorstwa H. Tadeusiewicz, gdyż „Roczniki Biblioteczne” nie uwzględniały łódzkiej Katedry. 
ukazały się pod redakcją Jerzego Jarowieckiego ${ }^{19}$. W Katowicach od 1983 roku zaczęły się ukazywać „Studia Bibliologiczne” — redagowane zespołowo dzieła monotematyczne ukazujące się z roczną częstotliwością. Celem publikacji było wspomaganie drogi awansu naukowego asystentów i adiunktów, lecz publikowali tam również doświadczeni badacze z tytułami naukowymi ${ }^{20}$. Wyższa Szkoła Pedagogiczna w Bydgoszczy w latach 1979-1994 wydała siedem zeszytów również zatytułowanych „Studia Bibliologiczne”. Redaktorem był Henryk Dubowik, a swoje prace zamieszczali pracownicy Zakładu/Katedry Bibliotekoznawstwa, Biblioteki WSP i osoby spoza uczelni ${ }^{21}$. W Łodzi, w latach 1981-1989, w ramach wydawnictwa zbiorowego „Acta Universitatis Lodziensis” ukazywała się seria „Folia Scientiarum Artium et Librorum". Cztery spośród dziewięciu zeszytów miały charakter bibliologiczny i zawierały wyłącznie prace pisane na stopień naukowy.

Stosunkowo rzadkim (w porównaniu do czasów obecnych) zjawiskiem były w latach 70. i 80. konferencje naukowe i będące ich efektem publikacje. Kilka konferencji metodycznych na temat kształcenia bibliotekarzy i innych pracowników książki zorganizowały w latach 70. instytuty: w Poznaniu, Olsztynie, Krakowie (Uniwersytet Jagielloński), Warszawie i Wrocławiu. We Wrocławiu miały też miejsce konferencje poświęcone badaniom regionalnym (ze szczególnym uwzględnieniem Śląska) oraz teorii i historii książki i bibliologii ${ }^{22}$. IBiIN Uniwersytetu Warszawskiego był w latach 70. i 80. organizatorem lub współorganizatorem konferencji krajowych i międzynarodowych. Dotyczyły one zarówno problemów współczesnych - informacji naukowej czy książki w grupach etnicznych - jak i tematyki historycznej - np. postaci Joachima Lelewela ${ }^{23}$. Kilka konferencji dotyczących problematyki bibliotekoznawczej zorganizował w drugiej połowie lat 70. młody jeszcze Zakład Bibliotekoznawstwa i Informacji Naukowej Uniwersytetu Śląskiego, niezależnie od sesji poświęconych badaniom historii książki na Śląsku ${ }^{24}$. Ważną dla budowania podstaw teoretycznych dyscypliny konferencję zorganizował w 1974 roku Instytut Bibliotekoznawstwa i In-

19 Halina GRZYWACZ, Adam RUTA, Instytut Informacji Naukowej i Bibliotekoznawstwa Uniwersytetu Pedagogicznego im. Komisji Edukacji Narodowej w Krakowie, Forum Bibliotek Medycznych 2013, nr 2 (12), s. 133.

20 Elżbieta GONDEK et al., Instytut Bibliotekoznawstwa i Informacji Naukowej Uniwersytetu Śląskiego w Katowicach. Droga od genezy po rok bieżacy (1974-2013), Forum Bibliotek Medycznych 2013, nr 2 (12), s. 54. Do roku 2015 wydano 20 tomów „Studiów Bibliologicznych”.

${ }^{21}$ Zdzisław KROPIDŁOWSKI, Katedra Informacji Naukowej i Bibliologii Uniwersytetu Kazimierza Wielkiego w Bydgoszczy, Forum Bibliotek Medycznych 2013, nr 2 (12), s. 37.

${ }^{22}$ Zob. Elżbieta HERDEN, Bożena KOREDCZUK, Badania naukowe w Instytucie Informacji Naukowej i Bibliotekoznawstwa Uniwersytetu Wrocławskiego w latach 1956-2006. Próba syntezy i oceny, [w:] Dokument, książka i biblioteka..., s. 197-198.

23 Zob. Katarzyna MATERSKA, Zarys problematyki badawczej realizowanej w Instytucie Informacji Naukowej i Studiów Bibliologicznych w latach 1951-2001, [w:] Warszawskie uniwersyteckie studia..., s. 61.

${ }^{24}$ Zob. E. GONDEK et al., op. cit., s. 51-53. 
formacji Naukowej w Poznaniu - Metodologia bibliotekoznawstwa i informacji naukowej. W organizowaniu konferencji miały też niewielki udział naukowe jednostki bibliotekoznawcze w wyższych szkołach pedagogicznych — w Bydgoszczy i w Krakowie ${ }^{25}$.

Spośród ośrodków akademickich dynamicznie rozwijały się instytuty w Warszawie i Wrocławiu. W IBiIN Uniwersytetu Warszawskiego liczba pracowników naukowo-dydaktycznych z dziesięciu w roku 1971 wzrosła do dwudziestu w roku 1981, na początku zaś lat 90 . w Instytucie pracowało już 35 osób ${ }^{26}$. Rozbudowana została w drugiej połowie lat 70. struktura wewnętrzna Instytutu (zakłady: Bibliotekoznawstwa, Historii i Teorii Bibliografii, Systemów Informacyjnych, Wiedzy o Dawnej Książce), adekwatnie do potrzeb dydaktycznych wynikających z wprowadzanych specjalizacji oraz tematyki realizowanych prac badawczych. Nieco wolniej zmiany te zachodziły w Instytucie Bibliotekoznawstwa Uniwersytetu Wrocławskiego - liczba etatowych pracowników naukowo-dydaktycznych wzrosła tam z 18 w roku 1971 do 22 w roku 1981 i 30 w roku 1991 (w tym 4 osoby na pół lub jedną trzecią etatu). Na początku lat 90 . znacząco wzrosła natomiast liczba samodzielnych pracowników naukowych — było ich aż ośmiu ${ }^{27}$.

Najstarszy polski akademicki ośrodek bibliotekoznawczy na Uniwersytecie Łódzkim, funkcjonujący od roku 1972 jako Zakład Informacji Naukowej i Bibliotekoznawstwa, wznowił w 1975/1976 kształcenie na studiach magisterskich (profil humanistyczno-społeczny), a w 1981 został przemianowany na Katedrę Bibliotekoznawstwa i Informacji Naukowej. Wraz z podjęciem na nowo działalności dydaktycznej rozpoczęto budowę nowego zespołu pracowników naukowych. $\mathrm{Na}$ początku lat 80 . potencjał naukowy Katedry wzmocnił się wskutek przejścia z Biblioteki Uniwersyteckiej dwojga pracowników — Janusza Dunina i Hanny Tadeusiewicz - którzy uzyskali wówczas stopnie doktora habilitowanego.

W pozostałych ośrodkach, które w większości rozpoczynały działalność w początkach lub w połowie lat 70., procesy organizacji studiów i badań naukowych przebiegały podobnie. Charakterystycznym zjawiskiem było, że pierwszymi kierownikami zakładów/katedr bibliotekoznawczych byli zazwyczaj przedstawiciele innych dyscyplin humanistycznych (filolodzy, historycy). Pierwszym kierownikiem Zakładu, a następnie Katedry Bibliotekoznawstwa na Uniwersytecie Jagiellońskim był w latach 1974-1994 historyk literatury polskiej — Stanisław

25 Zob. Kazimierz ADAMCZYK, Kształcenie bibliotekarzy w Bydgoszczy od II wojny światowej do 2007 roku, [w:] Od ksiązki dawnej do biblioteki wirtualnej - przeobrażenia bibliologii polskiej, Toruń 2009, s. 29-45; H. GRZYWACZ, A. RUTA, op. cit., s. 134.

26 Małgorzata KISILOWSKA, Pracownicy Katedry Bibliotekoznawstwa, Instytutu Bibliotekoznawstwa i Informacji Naukowej oraz Instytutu Informacji Naukowej i Studiów Bibliologicznych Uniwersytetu Warszawskiego 1951-2000, [w:] Warszawskie uniwersyteckie studia..., s. 99-104.

27 Sprawozdania Instytutu Bibliotekoznawstwa Uniwersytetu Wrocławskiego z lat 19711991, mps. 
Grzeszczuk (również dyrektor Biblioteki Jagiellońskiej w latach 1978-1981)28; Zakładem Bibliotekoznawstwa w Wyższej Szkole Pedagogicznej w Krakowie w pierwszych latach jego istnienia (1975-1978) kierował Jan Okoń — wybitny znawca literatury staropolskiej, a po nim Jerzy Jarowiecki — polonista; w Katowicach Adam Władysław Jarosz — również filolog polonista. Z kolei w Lublinie, w Kielcach, a także w Toruniu tamtejsze uczelniane placówki kształcenia bibliotekarzy organizowali głównie historycy (np. w Lublinie prof. Józef Szymański — kierownik Zakładu Nauk Pomocniczych Historii i Bibliotekoznawstwa od 1978 roku), a funkcjonowały one początkowo w ramach instytutów historiii ${ }^{29}$.

Spośród tych nowych placówek szczególnie dynamicznie rozwijał się Samodzielny (od 1977 roku) Zakład Bibliotekoznawstwa w Wyższej Szkole Pedagogicznej w Krakowie. Od 1981 roku prowadzono tam pięcioletnie studia magisterskie, a w roku akademickim 1985/1986 bibliotekoznawstwo uzyskało status kierunku nauczycielskiego. Podobnie dynamiczny rozwój stał się udziałem istniejącego od 1974 roku na Wydziale Filologicznym Uniwersytetu Śląskiego Zakładu Bibliotekoznawstwa i Informacji Naukowej. Lata 80 . nie były natomiast szczególnie pomyślne dla rozwoju akademickich ośrodków kształcenia bibliotekarzy w Bydgoszczy, Kielcach i Toruniu. Wynikało to głównie z braku wystarczającej liczby samodzielnych pracowników naukowych i było przyczyną czasowego zawieszania rekrutacji na studia.

\subsection{LATA $1990-2015$}

Zapoczątkowany na przełomie lat 80 . i 90 . XX wieku proces przemian społeczno-politycznych objął również środowisko akademickie. Kolejne ustawy o szkolnictwie wyższym $(1990,2005,2012)$ w prowadzały nowe rozwiązania w systemie kształcenia i organizacji procesu dydaktycznego. Studia bibliotekoznawcze przechodziły w tym okresie nie tylko wszystkie zapisane we wspomnianych ustawach przemiany strukturalne (standaryzacja programów, system boloński, krajowe ramy kwalifikacji, akredytacja kierunków), lecz musiały także, dostosowując się do zmian zachodzących w bibliotekach oraz w formach i metodach tworzenia, gromadzenia i przetwarzania informacji, realizować nowe programy, a z czasem także nowe kierunki studiów. Wszystkim tym zjawiskom towarzyszyły liczne dyskusje i publikacje, w których obok krytycznej oceny aktualnego stanu szkolnictwa bibliotekarskiego znaleźć można było wiele wartościowych postulatów odnośnie do jego przyszłości ${ }^{30}$. Urzędowym usankcjonowaniem procesów

28 Stownik pracowników książi polskiej. Suplement III, Warszawa: Wydaw. SBP 2010, s. $101-102$.

29 Informacje o poszczególnych placówkach na podstawie dotyczących ich opracowań cytowanych wcześniej w niniejszej pracy.

30 Zob. Agnieszka FLUDA-KROKOS, Problematyka ksztatcenia akademickiego pracowników bibliotek $i$ informacji naukowej na łamach czasopism specjalistycznych (1945-2015), [w:] Uniwersyteckie ksztatcenie bibliotekarzy..., s. 67-94. 
zmian zachodzących w obrębie dyscypliny było najpierw, w roku 1992, uznanie jej za jedną z 14 równorzędnych dyscyplin humanistycznych ${ }^{31}$, a następnie nadanie uchwałą Centralnej Komisji do Spraw Stopni i Tytułów z dnia 25 października 2005 roku nazwy — bibliologia i informatologia. Ten dualizm terminologiczny (również merytoryczny) znajduje też coraz częściej potwierdzenie w zmienianych nazwach uczelnianych instytutów i katedr oraz tworzonych nowych kierunkach studiów.

$\mathrm{Na}$ Uniwersytecie Warszawskim lata 90. przyniosły finansowane z programu TEMPUS zmiany w strukturze studiów (wyodrębnienie dwóch poziomów kształcenia i włączenie ich do europejskiego systemu mobilności studiów) z jednoczesną zmianą nazwy placówki na Instytut Informacji Naukowej i Studiów Bibliologicznych (1997), natomiast struktura organizacyjna Instytutu pozostała niezmieniona. Szczególnym wkładem placówki warszawskiej w rozwój polskiej bibliologii i informatologii w tym okresie było utworzenie i prowadzenie dwóch kolekcji cyfrowych - Bibliologicznej Biblioteki Cyfrowej i Polonijnej Biblioteki Cyfrowej $^{32}$. Rok 2016 natomiast przyniósł radykalną zmianę w organizacji warszawskiego ośrodka - w wyniku połączenia IINiSB z Instytutem Dziennikarstwa utworzono Wydział Dziennikarstwa, Informacji i Bibliologii.

Tak jak w poprzednim okresie nieco wolniej procesy przekształceń przebiegały w Instytucie Bibliotekoznawstwa Uniwersytetu Wrocławskiego, czego wyrazem stała się przeprowadzona dopiero w 2003 roku zmiana jego nazwy na Instytut Informacji Naukowej i Bibliotekoznawstwa. Niezależnie jednak od tego, od lat 90. znacząco zwiększała się liczba godzin dydaktycznych przeznaczonych w programie studiów na informację naukową. Co jednak najważniejsze, od początku lat 90. aż do 2005 roku pozostawał wrocławski ośrodek bibliotekoznawczy jedynym w Polsce ośrodkiem uprawnionym do prowadzenia przewodów habilitacyjnych w zakresie dyscypliny „bibliotekoznawstwo i informacja naukowo-techniczna”, a potem „bibliologia”.

Lata 90. zapoczątkowały okres intensywnego rozwoju bibliotekoznawstwa na Uniwersytecie Śląskim. Z początkiem dekady dotychczasowy Zakład Bibliotekoznawstwa i Informacji Naukowej przekształcił się w Instytut Bibliotekoznawstwa i Informacji Naukowej, a wydzielenie w jego obrębie kilku zakładów pozwoliło na bardziej optymalną organizację badań naukowych. Potwierdzeniem rozwoju organizacyjnego i naukowego tego instytutu było przyznanie mu w 2010 roku (jako

31 K. MIGOŃ, O nazwie dyscypliny, która uprawiamy, Przegląd Biblioteczny (61) 1993, z. $1 / 2$, s. 109 .

${ }^{32}$ Zob. K. MATERSKA, op. cit., s. 64-80; Mikołaj OCHMAŃSKI, Działalność Instytutu Informacji Naukowej i Studiów Bibliologicznych Uniwersytetu Warszawskiego. Wybrane prace badawcze, publikacje oraz wspótpraca z partnerami zagranicznymi, Przegląd Biblioteczny (66) 1998, z. 4, s. 339-345; Justyna JASIEWICZ, Między tradycja a nowoczesnością. Instytut Informacji Naukowej i Studiów Bibliologicznych Uniwersytetu Warszawskiego, Forum Bibliotek Medycznych 2014, nr 1 (13), s. 83-86; http://www.lis.uw.edu.pl/?page_id=137 [dostęp: 30 VIII 2016]. 
trzeciej placówce w Polsce, po instytutach wrocławskim i warszawskim) prawa do prowadzania postępowania w sprawie nadawania stopnia doktora habilitowanego.

Nie bez problemów odbywał się rozwój innych ośrodków. Łódzka Katedra Bibliotekoznawstwa i Informacji Naukowej, ponosząc na początku lat 90. konsekwencje wprowadzenia nowych wymogów Rady Głównej Szkolnictwa Wyższego, musiała ze względu na brak dostatecznej liczby samodzielnych pracowników naukowych przekształcić studia z zakresu bibliotekoznawstwa i informacji naukowej w specjalność w obrębie kierunku filologia polska.

Skutki nowych wymogów dotyczących obsady kadrowej odczuł również ośrodek bibliotekoznawczy na Uniwersytecie Mikołaja Kopernika w Toruniu na początku lat 90. Zorganizowanie jednak najpierw studiów licencjackich, później zaś uzupełniających magisterskich, a przede wszystkim rozwój naukowy pracowników przyczyniły się w 2004 roku do powołania Instytutu Informacji Naukowej i Bibliologii i w efekcie pozwoliły na uzyskanie uprawnień do przeprowadzania przewodów doktorskich, a od 2015 roku także habilitacyjnych ${ }^{33}$.

Instytut Informacji Naukowej i Bibliotekoznawstwa Uniwersytetu Jagiellońskiego jest jedyną w kraju placówką, która nie funkcjonuje w obrębie wydziału humanistycznego. Od połowy lat 90. Instytut ten jest częścią utworzonego wówczas Wydziału Zarządzania i Komunikacji Społecznej. Ten fakt, a także realizowane programy dydaktyczne (nowy kierunek — zarządzanie informacją) miały duży wpływ na charakter i tematykę podejmowanych badań naukowych.

Do powołania Instytutu Bibliotekoznawstwa i Informacji Naukowej na Uniwersytecie Marii Curie-Skłodowskiej w Lublinie doszło dopiero w roku 2003, mimo iż studia bibliotekoznawcze, jak wspomniano wcześniej, prowadzone były tam już od połowy lat 70 .

Instytut Informacji Naukowej i Bibliotekoznawstwa Uniwersytetu Pedagogicznego w Krakowie w latach 90. i na przełomie wieków przechodził liczne zmiany organizacyjne. Były one przede wszystkim efektem zmian statusu samej uczelni, która w roku 1999 została przekształcona w Akademię Pedagogiczną im. Komisji Edukacji Narodowej, a w roku 2008 stała się Uniwersytetem Pedagogicznym, również imienia KEN. Obecna struktura wewnętrzna Instytutu (trzy katedry) potwierdza możliwości prowadzenia badań z obszaru zarówno szeroko pojętej bibliologii, jak i informatologii.

Studia bibliotekoznawcze na Uniwersytecie Jana Kochanowskiego w Kielcach prowadzone są przez Instytut Bibliotekoznawstwa i Dziennikarstwa, utworzony w 1998 roku w ówczesnej Wyższej Szkole Pedagogicznej. Od roku 2010/2011 w Instytucie prowadzony jest także kierunek Dziennikarstwo i Komunikacja społeczna ${ }^{34}$.

33 Janusz TONDEL, Trzydzieści lat studiów bibliotekoznawczych w Toruniu, [w:] Od książki dawnej do biblioteki wirtualnej..., s. 13-27.

34 http://idi.ujk.edu.pl/historia-instytutu/. 
Katedra Informacji Naukowej i Bibliologii powstała w 1991 roku (wcześniej funkcjonowała jako Zakład) w Wyższej Szkole Pedagogicznej w Bydgoszczy - poprzedniczce obecnego Uniwersytetu Kazimierza Wielkiego. Pomimo problemów z utrzymaniem ciągłości studiów w Katedrze systematycznie budowano kadrę naukową i rozbudowywano strukturę organizacyjną, na którą składają się obecnie trzy zakłady ${ }^{35}$.

Pewien udział w rozwoju polskiej bibliologii miał też utworzony na Uniwersytecie w Białymstoku w roku akademickim 2008/2009 Zakład Informacji Naukowej i Bibliotekoznawstwa (wcześniej, od 1998, jako Zakład Bibliotekoznawstwa). Organizatorem i pierwszym kierownikiem Zakładu była Anna Sitarska. Dalsze istnienie białostockiej placówki jest jednak zagrożone ze względu na zawieszenie w roku akademickim 2014/2015 rekrutacji kandydatów. Obecnie w Białymstoku bibliotekoznawstwo prowadzone jest jedynie jako specjalność współczesne bibliotekarstwo i informacja naukowa na studiach I stopnia filologii polskiej ${ }^{36}$.

Po roku 1990 wskutek zmian systemu prawnego sankcjonującego powoływanie uczelni niepublicznych, przy jednoczesnym zagwarantowaniu autonomii szkół wyższych nastąpił wzrost liczby ośrodków podejmujących kształcenie bibliotekarzy. W latach 90. najczęściej organizowano studia podyplomowe, lecz po wprowadzeniu systemu bolońskiego (2005) — także studia licencjackie. Jednak wąte z reguły możliwości kadrowe i materialne niektórych ośrodków w połączeniu z postępującym niżem demograficznym i „dzięki” tzw. deregulacji ${ }^{37}$ stopniowo zweryfikowały ambitne zamierzenia tych uczelni. Ich udział w procesie kształcenia nadal się kurczy, a w rozwoju badań naukowych rzadko był dostrzegalny.

\section{BADANIA NAUKOWE}

\subsection{UWARUNKOWANIA DZIAŁALNOŚCI NAUKOWO-BADAWCZEJ}

Kierunki badań prowadzonych na przestrzeni omawianych 70 lat w poszczególnych ośrodkach naukowych zależały od wielu czynników — wewnętrznych i zewnętrznych. Do pierwszych można zapewne zaliczyć wielkość placówki i liczbę nauczycieli akademickich, lecz także realizowany program dydaktyczny

35 http://www.kinib.ukw.edu.pl//jednostka/katedra_informacji_naukowej/historia_bibliotekoznawstwo/.

36 Katarzyna ZIMNOCH, Z historii studiów bibliotekarskich na Uniwersytecie w Biatymstoku, Forum Bibliotek Medycznych 2014, nr 1 (13), s. 30-34; eadem, Kształcenie bibliotekarzy na Uniwersytecie w Biatymstoku (1991-2015), [w:] Uniwersyteckie ksztatcenie bibliotekarzy..., s. $127-135$.

37 Rozporządzenie Ministra Kultury i Dziedzictwa Narodowego z dnia 5 grudnia 2012 roku w sprawie wymagań kwalifikacyjnych uprawniających do zajmowania w bibliotekach stanowisk bibliotekarskich oraz stanowisk dla specjalistów innych zawodów związanych z działalnością biblioteczną, Dziennik Ustaw 2012 poz. 1394. 
(wersja humanistyczna lub matematyczna), określone tradycje badawcze, strukturę jednostki i jej usytuowanie w obrębie uczelni oraz osobowość dyrektora/ kierownika.

Wśród czynników określonych jako zewnętrzne (zmieniały się z biegiem lat i zmianami ustroju) trzeba wymienić równoległe istnienie wielu innych instytucji naukowych, w których również podejmowano prace naukowo-badawcze z zakresu szeroko pojmowanej nauki o książce, chociaż nie było to głównym celem działalności tych placówek. Były to (i są nadal) obok Biblioteki Narodowej z jej wyspecjalizowanymi instytutami (Instytut Bibliograficzny, Instytut Książki i Czytelnictwa, Zakład Starych Druków) biblioteki uczelniane, zwłaszcza książnice uniwersyteckie, samodzielne biblioteki Polskiej Akademii Nauk z Biblioteką Zakładu Narodowego Ossolińskich (obecnie już poza siecią PAN) na czele oraz niektóre wielkomiejskie biblioteki publiczne o statusie naukowym. Jedynym w okresie PRL samodzielnym bibliologicznym ośrodkiem naukowo-badawczym był funkcjonujący w Łodzi w latach 1946-1949 Państwowy Instytut Książki ${ }^{38}$.

Na kierunek, charakter i tematykę badań podejmowanych zwłaszcza w latach 50. i 60. XX wieku pewien wpływ wywarła również nieprecyzyjna terminologia, a szczególnie brak ustaleń odnośnie do wzajemnych relacji między bibliotekoznawstwem i księgoznawstwem. Jednoznacznemu rozgraniczeniu zakresu i potencjału naukowego tych dyscyplin nie sprzyjało także użycie terminu „bibliotekoznawstwo" w nazwach powstałych wówczas katedr oraz prowadzonych przez nie kierunkach studiów wyższych, których programy od początku obejmowały jednak głównie obszar nauki o książce. Ostre niejednokrotnie polemiki prowadzone na łamach naukowych czasopism fachowych ${ }^{39}$, lecz przede wszystkim ustalenia teoretyczne i faktograficzne ówczesnych badaczy (głównie Karola Głombiowskiego i jego współpracowników) przyczyniły się w końcu do wypracowania ustaleń dotyczących przedmiotu, metody i zadań obydwu dyscyplin.

W panującym w PRL systemie scentralizowanym wpływ na kierunki i charakter prowadzonych na uczelniach badań miała też administracja rządowa, a konkretnie Ministerstwo Szkolnictwa Wyższego, które finansowało określone programy badawcze. Były to tzw. tematy główne, węzłowe, resortowe lub międzyresortowe. Jednym z tematów węzłowych, w którym uczestniczyli pracownicy kilku instytutów i katedr bibliotekoznawstwa, był temat Polska kultura narodowa, jej tendencje rozwojowe i percepcja w działach VII A Upowszechnianie ksiażki, czytelnictwo i VII B Ksiązka w procesie komunikacji społecznej, przykładem zaś

38 Więcej o działalności tych instytucji zob. H. WIĘCKOWSKA, Organizacja, stan i kierunki..., s. 45-77; Krzysztof MIGOŃ, Z dziejów nauki o książce, Wrocław: Zakład Narod. im. Ossolińskich 1979, s. 124-129; także odpowiednie hasła w Encyklopedii wiedzy o książce, Wrocław: Zakład Narod. im. Ossolińskich 1971.

39 Głównymi uczestnikami dyskusji byli Karol Głombiowski i Władysław Piasecki. 
problemu resortowego było zagadnienie Społeczne problemy informacji w dobie automatyzacji systemów informacyjnych w nauce.

Przemiany zapoczątkowane na przełomie lat 80 . i 90 . korzystnie wpłynęły na możliwości prowadzenia przez pracowników uczelni działalności naukowowo-badawczej. Wskutek zmian politycznych (zniesienie cenzury), ekonomicznych (m.in. likwidacja przydziałów papieru) i dzięki postępującej komputeryzacji publikowanie wyników prac naukowych stało się znacznie łatwiejsze niż w poprzednich dziesięcioleciach, zwłaszcza że każdy ośrodek począł wydawać własny periodyk (czasami dwa). Prowadzona w ostatnich latach polityka naukowa państwa (m.in. system grantów) i stosowany system punktacji, ważny w procesie parametryzacji jednostek, zachęcają przede wszystkim do publikowania w wysoko punktowanych czasopismach (najlepiej w języku angielskim). Szczególną rolę w procesach upowszechniania wyników badań bibliologicznych odegrało jednak Stowarzyszenie Bibliotekarzy Polskich, powołując do życia niezwykle prężną instytucję edytorską - Wydawnictwo Stowarzyszenia Bibliotekarzy Polskich, które w ramach serii „Nauka - Dydaktyka - Praktyka” publikuje znaczącą część przygotowywanych w poszczególnych jednostkach akademickich opracowań. Stopniowo coraz bardziej popularną formą organizacji życia naukowego stawały się konferencje naukowe (nie tylko krajowe), kończące się zazwyczaj publikowaniem wygłaszanych referatów. Organizowały je wszystkie ośrodki, przy czym niektóre z nich zaczęły się specjalizować w określonej problematyce, jak Kraków-Lwów. Ksiązki — czasopisma - biblioteki Instytutu Bibliotekoznawstwa Uniwersytetu Pedagogicznego czy Książka, biblioteka, informacja - między podziałami i wspólnota organizowana od 2006 roku przez Instytut kielecki, problematyce cenzury organizowanych przez Instytut toruński, edukacji z bibliotekoznawstwa i informacji naukowej organizowanych przez IINiB Uniwersytetu Jagiellońskiego (w latach 1995-2011 łącznie 17 konferencji) ${ }^{40}$. Istotnym elementem stymulującym rozwój badań naukowych stała się współpraca międzynarodowa realizowana zarówno w drodze wyjazdów indywidualnych (w ramach programów Erasmus i innych), jak i w organizacji, wspólnych z zagranicznymi placówkami, konferencji, sympozjów i seminariów.

Ogromny wpływ na ukierunkowanie badań naukowych, oprócz przemian polityczno-ustrojowych, wywarła dokonująca się na przełomie wieków rewolucja informacyjna i upowszechnienie cyfryzacji. Wszystkim tym zmianom towarzyszyły debaty dotyczące teoretycznych i metodologicznych podstaw bibliologii,

40 Izabela KRASIŃSKA, Instytut Bibliotekoznawstwa i Dziennikarstwa Uniwersytetu Jana Kochanowskiego w Kielcach, Forum Bibliotek Medycznych 2013, nr 2 (12), s. 66-119; http:// idi.ujk.edu.pl/category/nauka/ [dostęp: 22 VIII 2016]; E. HERDEN, B. KOREDCZUK, op. cit., s. 181-199; Monika JAREMKÓW, Instytut Informacji Naukowej i Bibliotekoznawstwa Uniwersytetu Wrocławskiego - umiejętne (po)taczenie tradycji i nowoczesności, Forum Bibliotek Medycznych 2013, nr 2, s. 178-187; http://www.ibi.uni.wroc.pl/projekty-badawcze-realizowane-w-inib [dostęp: 30 VIII 2016]; http://www.bu.uni.wroc.pl/publikacje/ [dostęp: 30 VIII 2016]. 
zredefiniowania jej paradygmatu badawczego, z jednoczesnymi próbami określenia głównego elementu programów studiów bibliotekoznawczych. Oprócz koncepcji „kultury książki” jako centralnej kategorii badawczej w badaniach bibliologicznych ${ }^{41}$ coraz ważniejsze miejsce zdobywa wynikająca $\mathrm{z}$ dynamicznego rozwoju technologii cyfrowych tendencja do uczynienia głównym przedmiotem badań bibliologicznych pojęcia informacji „nieograniczonej tylko do sfery nauki, jednak ujętej w ramy humanistyczne i kulturowe, podlegającej nowoczesnym procesom gromadzenia, rzetelnego opracowania i udostępniania, obejmującej procesy jej wytwarzania oraz upowszechniania zarówno w ujęciu historycznym, jak i współczesnym" 42 . Ten dualizm terminologiczny (również merytoryczny i metodologiczny) znajdował wyraz w rozwoju nowych nurtów badawczych.

\subsection{KIERUNKI PROWADZONYCH BADAŃ}

Rozwój nauki o książce w powojennym siedemdziesięcioleciu swoje źródło miał bezsprzecznie w wielkich książnicach naukowych. Wszyscy twórcy pierwszych uniwersyteckich ośrodków bibliotekoznawczych - Jan Muszkowski (Łódź), Aleksander Birkenmajer (Warszawa) oraz Antoni Knot i Karol Głombiowski (Wrocław) - mieli za sobą długoletni staż pracy w bibliotekach naukowych i jedynie z wyjątkiem K. Głombiowskiego przez wiele lat kierowali takimi instytucjami. Niezależnie od charakteru ukończonych studiów (nauki ścisłe, humanistyczne, społeczne) w ich, często bogatym, dorobku naukowym przeważały zdecydowanie prace z obszaru nauk bibliologicznych, przy czym J. Muszkowski i A. Birkenmajer kontynuowali badania prowadzone $z$ dużym sukcesem jeszcze przed rokiem 1939.

Pierwszy z nich rozwijał i pogłębiał sformułowaną przed wojną teorię nauki o książce, publikując na ten temat wiele artykułów i drugą edycję (Kraków 1951) wydanego w 1936 roku Życia książki. Jednocześnie dostrzegając dużą pojemność terminu „dokument” i zdając sobie sprawę, że książka jest jednym z rodzajów dokumentów graficznych, sugerował istnienie, obok bibliologii, odrębnej dyscypliny, czyli informacji naukowej, którą nazywał jednak dokumentacją (Dokumentacja i dokumentologia, „Życie Nauki” 1946, nr 9/10). W kręgu zainteresowań naukowych Muszkowskiego w latach powojennych ważne miejsce zajmowały też problemy akademickiego kształcenia bibliotekarzy, co pozostawało, rzecz jasna, w ścisłym związku z jego działalnością naukowo-dydaktyczną.

${ }^{41}$ K. MIGOŃ, Kultura książki. Program dla bibliologii i potrzeba dla studiów bibliotekoznawczych, [w:] Nauka o książce, bibliotece i informacji we współczesnym świecie, Warszawa: Wydaw. SBP 2003, s. 11-20.

${ }^{42}$ Marta GRABOWSKA, Informacja - ten niezwykty przedmiot badań. Od bibliologii do nauki o informacji, [w:] Bibliologia i informatologia. Pod red. Dariusza Kuźminy, Warszawa: Polskie Tow. Bibliologiczne 2011, s. 201. 
A. Birkenmajer także podejmował próby wypracowania ujęć teoretycznych w zakresie księgoznawstwa, skupiając się jednak (głównie w okresie międzywojennym) na książce rękopiśmiennej. Jako wybitny znawca rękopisów średniowiecznych i dawnej książki opublikował wiele prac poświęconych oprawom, historii drukarstwa i bibliotek. W okresie powojennym Birkenmajer wniósł znaczący wkład do uporządkowania terminologii oraz zakreślenia i rozgraniczenia pola badawczego bibliotekoznawstwa i bibliologii ${ }^{43}$. Swoje poglądy na treść bibliotekoznawstwa sformułował Birkenmajer już w latach 20. XX wieku, przedstawiając konspekt akademickiego podręcznika bibliotekarstwa naukowego 44 . Planowany podręcznik wprawdzie nigdy się nie ukazał, lecz główne założenia zawartej w nim koncepcji kształcenia bibliotekarzy wprowadził Birkenmajer w organizacji studiów na Uniwersytecie Warszawskim. Twórca warszawskiej Katedry odszedł bowiem od realizowanego przez J. Muszkowskiego modelu studiów bibliologicznych na rzecz programu skonstruowanego wokół dwóch równoległych tematów — książki i biblioteki. Ten bibliotekoznawczo-informacyjny (z czasem) model będzie kontynuowany przez następców Birkenmajera, co znajdzie wyraz również w podejmowanych przez pracowników badaniach naukowych.

Inne uwarunkowania towarzyszyły zainicjowaniu badań naukowych we Wrocławiu. Ze względu na wykształcenie i zainteresowania naukowe twórcy i koryfeusza wrocławskiego bibliotekoznawstwa - A. Knota — przyjęły one zrazu charakter przede wszystkich historyczny. Takiemu ukierunkowaniu badań we Wrocławiu sprzyjał fakt, że w mieście funkcjonowało kilka książnic naukowych mających bogate zbiory (Ossolineum, Biblioteka Uniwersytecka, Biblioteka Kapitulna), które stanowiły warsztat badawczy tamtejszych pracowników naukowych. Z czasem dopiero pojawił się teoretyczny nurt badawczy, co było przede wszystkim zasługą Karola Głombiowskiego 45 .

Najbardziej rozbudowane programy badawcze miały w pierwszych dziesięcioleciach omawianego okresu katedry, a później instytuty — warszawski i wrocławski - i od nich należy zacząć omówienie kierunków badań naukowych realizowanych w akademickich ośrodkach bibliotekoznawczych.

2.2.1. OŚRODEK WARSZAWSKI

Badania naukowe w Katedrze Bibliotekoznawstwa Uniwersytetu Warszawskiego pozostawały w pierwszych latach istnienia placówki niemal wyłącznie

43 A. BIRKENMAJER, Bibliotekoznawstwo polskie: jego przeszłość, stan obecny i perspektywy na przyszłość, [w:] idem, Studia bibliologiczne, Wrocław 1975. Jest to tekst referatu, jaki Birkenmajer wygłosił na I Kongresie Nauki Polskiej w 1950 r.

44 Plan projektowanego podręcznika zaprezentował Birkenmajer w 1923 r. na Międzynarodowym Kongresie Bibliotekarzy i Bibliofilów w Paryżu. Zob. H. WIĘCKOWSKA, Akademickie ksztatcenie bibliotekarzy..., s. 25-27, 64-69.

45 A. ŻBIKOWSKA-MIGOŃ, Prace naukowo-badawcze w Instytucie Bibliotekoznawstwa Uniwersytetu Wrocławskiego (1956-1976), Roczniki Biblioteczne (21) 1977, z. 1/2, s. 486-487. 
udziałem profesora A. Birkenmajera i dopiero z czasem, wraz z zatrudnianiem kolejnych asystentów i samodzielnych pracowników nauki, obszar prowadzonych badań naukowych zaczął się poszerzać i różnicować ${ }^{46}$. Ogłaszane w latach 50 . XX wieku i w początkach następnej dekady opracowania naukowe pracowników lokowały się w dwóch równoległych nurtach. Pierwszym była orientacja bibliologiczna z przewagą problematyki historycznej, drugi nurt natomiast koncentrował się wokół zagadnień współczesności i przyszłości bibliotekarstwa, ze szczególnym zwróceniem uwagi na problematykę kształtowania optymalnych struktur i narzędzi oddziaływania instytucji bibliotecznych. Z czasem doszedł trzeci nurt — informacji naukowej. Wokół tych trzech bloków zagadnień, tj. 1) książki i jej roli w kulturze polskiej XVI-XX wieku, 2) biblioteki jako systemu i jednocześnie jako części systemów informacyjnych oraz 3) informacji naukowej, jej podstaw matematyczno-lingwistycznych, źródeł i związków z naukoznawstwem, skupiły się w kolejnych latach badania naukowe na Uniwersytecie Warszawskim ${ }^{47}$.

Historyczno-bibliologiczny kierunek w badaniach nad książką zainicjowany przez A. Birkenmajera kontynuował Ksawery Świerkowski, który większość swych prac poświęcił dziejom warszawskich instytucji książki (m.in. Rodowód Towarzystwa Biblioteki Publicznej w Warszawie, [w:] Z dziejów książki i bibliotek w Warszawie, Warszawa 1961) oraz A. Czekajewska-Jędrusik, w której kręgu zainteresowań pozostawała problematyka kultury książki w Polsce epoki renesansu, a także zagadnienia historii nauki i naukoznawstwa (m.in. O listach dedykacyjnych w polskiej ksiażce drukowanej XVI w., „Roczniki Biblioteczne” 1962, z. 1-2, i Dwadzieścia lat polskiej erazmianistyki, „Kwartalnik Historii Nauki” 1966, nr 4). Poczynając od końca lat 60., badania nad dawną książką, z uwzględnieniem jej miejsca w nauce, oświacie i wychowaniu, aspektów wydawniczych, zainteresowań czytelniczych, a także funkcji książki jako środka przekazywania treści, rozwijały się niezwykle intensywnie, głównie za sprawą Barbary Bieńkowskiej, autorki wielu książek i artykułów z tego zakresu (Staropolski świat książek, Warszawa 1976, i wspólnie z H. Chamerską Zarys dziejów ksiązki, Warszawa 1987). Szczególne miejsce w tych badaniach zajmowała historia książki w Warszawie, czym od lat 60. zajmowali się Andrzej Skrzypczak (Sennewaldowie. Księgarze $i$ wydawcy warszawscy, Wrocław 1969) i Marianna Mlekicka (m.in. Jakub Mortkowicz - księgarz i wydawca, Wrocław 1974 i Wydawcy ksiażek w Warszawie w okresie zaborów, Warszawa 1987), a później także m.in. Józef Wojakowski (Biblioteka Królewskiego Korpusu Kadetów w Warszawie, Warszawa 1989).

Nurt badań nad współczesnym bibliotekarstwem i czytelnictwem realizowało w pierwszych latach istnienia Katedry kilka osób, przede wszystkim Krystyna

46 A. RADZIEJOWSKA-HILCHEN, op. cit., s. 81-97.

47 ANNA CZEKAJEWSKA-JĘDRUSIK, Instytut Bibliotekoznawstwa i Informacji Naukowej. 25 lat historii, kierunki rozwoju, Przegląd Biblioteczny 1978, z. 2, s. 125. 
Remerowa, Z. Brzozowska i A. Niemczykowa. Pierwsza, będąc jednocześnie dyrektorem Instytutu Książki i Czytelnictwa Biblioteki Narodowej, umiejętnie wiązała dydaktykę z badaniami naukowymi i eksperymentalnymi. Jej zasługą było rozwijanie problematyki bibliotekoznawczej, a z czasem także informacyjnej (m.in. Zmiany funkcji bibliotek w powojennym dwudziestoleciu, Warszawa 1966). W tym nurcie badań mieściły się także problemy socjologii książki i czytelnictwa (m.in. Z. Brzozowska, Andersen w Polsce. Historia recepcji wydawniczej, Warszawa 1970), kształcenia bibliotekarzy oraz badania nad bibliotekami szkolnymi i pedagogicznymi, ich zadaniami i organizacją oraz nauki o bibliotece (m.in. A. Niemczykowa, J. Fercz, Wstęp do nauki o książce i bibliotece, Warszawa 1972 i następne wydania).

Badania stawiające w centrum zainteresowania biblioteki jako instytucje sytuujące się na tle szeroko pojmowanego otoczenia społecznego były kontynuacją nurtu zapoczątkowanego u zarania Katedry przez jej założyciela i pierwsze współpracownice. Wychowankowie A. Niemczykowej - Marcin Drzewiecki i Anna Radziejowska-Hilchen — rozwijali badania nad miejscem bibliotek szkolnych i pedagogicznych w systemie oświaty i kultury (m.in. M. Drzewiecki, Wspótczesna biblioteka szkolna, Warszawa 1980) oraz możliwościami ich unowocześniania. Zakres tematyczny tych badań ulegał stopniowemu poszerzeniu dzięki rozwinięciu współpracy z przedstawicielami historii literatury (m.in. Joanna Papuzińska, Inicjacje literackie. Problemy pierwszych kontaktów dziecka z ksiązka, Warszawa 1981) i pedagogiki. Inny punkt widzenia na funkcjonowanie współczesnych bibliotek prezentowała natomiast Anna Sitarska. W książce Systemowe badanie bibliotek. Studium metodologiczne (Łódź 1990) udowodniała, że istnieje pewna systemowa jedność łącząca wszystkie typy bibliotek i dzięki temu ich działanie przyczynia się do powstawania wspólnoty kulturowej.

Dostrzegając zmiany zachodzące we współczesnym świecie, zwłaszcza w obszarze szeroko rozumianej informacji, w latach 60. stopniowo rozwijano badania dotyczące metod pozyskiwania, organizacji, przetwarzania i prezentacji informacji. Pierwsze prace z tego zakresu podejmowała Regina Hancko (Zarys wiadomości o dokumentach, Warszawa 1972), a organizatorką specjalizacji w zakresie informacji naukowej była Halina Chamerska. Historyk z wykształcenia potrafiła jednak, nie tylko we własnej pracy badawczej, umiejętnie łączyć obie dziedziny (Stużba informacyjna w bibliotekach, Warszawa 1961, i Działalność bibliotek $w$ dziedzinie informacji naukowej w XXV-leciu PRL, Warszawa 1972).

Jednak dopiero matematyczno-społeczny model studiów bibliotekoznawczych, wprowadzony przez warszawski Instytut od roku 1975, dał nowe szanse kontynuowania badań w zakresie szeroko pojętej informacji naukowej. się na Zachodzie, a w Polsce dopiero raczkująca, automatyzacja systemów bibliotecznych stała się jeszcze w pierwszej połowie lat 70. przedmiotem zainteresowania A. Sitarskiej (Program rozwoju automatyzacji w Bibliotece Narodowej, 1973). Za 
istotne i unikatowe w skali krajowych ośrodków bibliotekoznawczych uznaje się prowadzone w IBiIN Uniwersytetu Warszawskiego prace dotyczące teorii języków informacyjno-wyszukiwawczych i ich praktycznego zastosowania ${ }^{48}$. Tego typu badania zapoczątkowała Ewa Chmielewska-Gorczyca pracą Indeksy permutacyjne (Warszawa 1977), a od połowy lat 70. z jej udziałem pracowała grupa badaczek (Barbara Sosińska-Kalata, Jadwiga Woźniak, Elżbieta Artowicz) zajmujących się budową i terminologią języków informacyjno-wyszukiwawczych. Efektem ich pracy był m.in. opublikowany w 1993 roku Stownik encyklopedyczny terminologii języków i systemów informacyjno-wyszukiwawczych pod red. Bożenny Bojar.

Nowym nurtem badawczym warszawskiego Instytutu, o charakterze historycznym, stały się po roku 1990 kwestie restytucji polskich dóbr kulturalnych (prace m.in. B. Bieńkowskiej, Urszuli Paszkiewicz i Jacka Puchalskiego). Jednocześnie rozszerzano zasięg chronologiczny dotychczasowych badań historycznych (aż do średniowiecza) przez podejmowanie zagadnień kultury książki, historii bibliotek i informacji w społeczeństwie wielonarodowościowym i wielokulturowym (prace Andrzeja Skrzypczaka, Edwarda Potkowskiego, J. Wojakowskiego, Dariusza Kuźminy). Ujęcie historyczne było też ważną częścią badań prowadzonych w Zakładzie Historii, Teorii i Metodyki Bibliografii (przez Paulinę Buchwald-Pelcową, A. Skrzypczaka, Mikołaja Ochmańskiego), przy jednoczesnym podejmowaniu zagadnień wchodzących w zakres metodyki bibliografii, a także kwestii digitalizacji zbiorów bibliotecznych i bibliografii w środowisku sieciowym (zajmowała się tym m.in. Marta Grabowska). Z kolei w Zakładzie Bibliotekoznawstwa kontynuowano badania dotyczące problemów współczesnego bibliotekarstwa: bibliotek szkolnych, pedagogicznych, więziennych i biblioterapii (M. Drzewiecki, Elżbieta Barbara Zybert), organizacji i zarządzania bibliotekami (E.B. Zybert, Małgorzata Kisilowska) i zastosowania metod marketingowych w bibliotekarstwie (Radosław Cybulski). Nowa rzeczywistość ekonomiczna zainspirowała do badania rynku książki i zagadnień marketingu bibliotecznego, także w odniesieniu do książki dziecięcej (R. Cybulski, Michał Zając). Rozwój mediów i nowoczesnych technologii informacyjnych wyznaczały nowe kierunki badań w prężnie rozwijającym się już w latach 80 . Zakładzie Systemów Informacyjnych. Obecnie obejmują one zagadnienia teorii i praktycznego wykorzystania języków informacyjno-wyszukiwawczych, organizacji i reprezentacji wiedzy, zarządzania informacją i wiedzą, wykorzystania zasobów informacji, zarówno tradycyjnych, jak i nowoczesnych oraz książki elektronicznej (Jadwiga Woźniak-Kasperek, B. Sosińska-Kalata, Mieczysław Muraszkiewicz, Katarzyna Materska, Dariusz Grygrowski).

${ }^{48}$ K. MATERSKA, op. cit., s. 75. 


\subsubsection{OŚRODEK WROCŁAWSKI}

Silnym ośrodkiem rozwijania, najpierw regionalnego nurtu badań nad dawną książką, a z czasem także ważnych uogólnień teoretycznych stała się Katedra Bibliotekoznawstwa na Uniwersytecie Wrocławskim, czemu sprzyjało istnienie już wcześniej programu badań nad historią książki na Śląsku, a także systematyczna rozbudowa etatowa Katedry.

W rozwijaniu badań regionalnych mieli w tym początkowym okresie udział głównie pracownicy związani wcześniej z Biblioteką Uniwersytetu Wrocławskiego. Wspomniany już B. Kocowski, finalizując swoje wcześniejsze badania z zakresu inkunabulistyki i historii śląskiego drukarstwa, opublikował w latach 1962 1977 trzytomowy Katalog inkunabułów Biblioteki Uniwersyteckiej we Wrocławiu. K. Głombiowski zajął się recepcją wybranych dzieł lub autorów na Śląsku w XVXVIII wieku (m.in. Polska literatura polityczna na Śląsku od XVI do końca XVIII w. Studium z zakresu historii użytkowania książki, Katowice 1960), a recepcją książki obcojęzycznej — Krzysztof Migoń (Recepcja książki orientalistycznej na Śląsku do końca XVIII wieku, Wrocław 1969), Anna Żbikowska-Migoń (Literatura angielska $w$ katalogu czytelnika wrocławskiego $w$ XVIII wieku, „Acta Universitatis Vratislaviensis. Bibliotekoznawstwo" 5, Wrocław 1968) i Kazimiera Maleczyńska (Recepcja książki francuskiej we Wrocławiu w XVI wieku, Wrocław 1967). Historię papieru i papiernictwa na Śląsku badała K. Maleczyńska (Dzieje starego papiernictwa śląskiego, Wrocław 1961), a dzieje książki polskiej we Wrocławiu w XVIII i XIX wieku Aleksandra Mendykowa (m.in. Kornowie, Wrocław 1980). Swego rodzaju podsumowaniem podejmowanych we Wrocławiu badań księgoznawczych dotyczących tego regionu była opublikowana w 1978 roku praca zbiorowa 500-lecie polskiego słowa drukowanego na Ślasku, materiaty sesji naukowej 9-11 X 1975 (Wrocław 1978), w której znalazły się artykuły dotyczące historii drukarstwa, bibliotekarstwa i obiegu książki na Śląsku takich autorów, jak: B. Kocowski, K. Migoń, A. Żbikowska-Migoń, Maria Przywecka-Samecka, K. Maleczyńska, Aleksandra Mendykowa.

Z czasem jednak historyczny nurt śląskoznawczy stał się tylko jednym z kierunków badawczych, a wielu badaczy zaczęło przejawiać zainteresowanie kulturą książki w aspekcie historycznym, także w innych regionach Polski. Dotyczyło to m.in. prekursorskich prac Marii Przyweckiej ukazujących dzieje drukarstwa muzycznego (m.in. Drukarstwo muzyczne w Polsce do końca XVIII wieku, Kraków 1969) czy prac K. Maleczyńskiej dotyczących dziejów polskich bibliotek w XIX wieku. Osiemnastowiecznej kulturze polskiej książki poświęcił wiele prac Józef Szczepaniec (m.in. Drukarstwo, gabinety $i$ wypożyczalnie literatury w Polsce w drugiej połowie XVIII wieku, Wrocław 1983, a zwłaszcza Drukarnia Wolna Jana Potockiego w Warszawie 1788-1792, Wrocław 1998). Szczególnym obiektem zainteresowania stały się Rzeczpospolita Krakowska i Galicja w okresie przed uzyskaniem autonomii (m.in. Artur Pilak, Księgarstwo w Rzeczypospolitej 
Krakowskiej (1815-1846), „Roczniki Biblioteczne” 1975, z. 1/2, i Anna Aleksiewicz, Drukarstwo w Rzeczypospolitej Krakowskiej i Galicji Zachodniej w latach 1815-1860, Wrocław 1976), Wielkopolska XIX wieku (m.in. Stefan Kubów, Ksiażka Wielkiej Emigracji w Wielkopolsce (1831-1862), Wrocław 1980) oraz ziemie wschodnie dawnej Rzeczypospolitej XVI-XVIII wieku (m.in. Maria Pidłypczak-Majerowicz, Bazylianie w Koronie $i$ na Litwie. Szkoły i książki w działalności zakonu, Wrocław 1986).

Ważnym nurtem badawczym stały się we wrocławskim Instytucie prace z zakresu teorii nauki o książce. K. Głombiowski sformułował wiele uogólnień teoretyczno-historycznych i znacznie poszerzył dotychczasowe pole badań nauki o książce, zapoczątkowując tzw. koncepcję funkcjonalną w badaniach bibliologicznych (m.in. O funkcjonalna koncepcję nauki o książce, "Studia o Książce” 1970; już po przeniesieniu się z Wrocławia do Gdańska ukazała się jego fundamentalna monografia Ksiażka w procesie komunikacji społecznej, Wrocław 1980). $\mathrm{Z}$ inspiracji K. Głombiowskiego rozwijano badania nad społeczną funkcją książki i bibliotek, lecz przede wszystkim kontynuowano nurt teoretyczny w badaniach księgoznawczych. Największe zasługi w zakresie uporządkowania przedmiotu, zakresu badawczego i metodologii nauki o książce położył uczeń K. Głombiowskiego - Krzysztof Migoń. W obszernym opracowaniu (poprzedzonym kilkoma innymi podejmującymi ten temat) zatytułowanym Nauka o ksiażce. Zarys problematyki, opublikowanym w 1984 roku, udowodnił, iż bibliologia jest dyscypliną o ugruntowanej już pozycji naukowej. Dalsze prace K. Migonia, a także innych badaczy spowodowały, że o prowadzonych we Wrocławiu badaniach poczęto mówić jako o „wrocławskiej szkole bibliologicznej”49. W tym nurcie mieściły się także prace Anny Żbikowskiej-Migoniowej na temat kształtowania się bibliologii jako odrębnej dyscypliny naukowej (Historia ksiązki w XVIII wieku. Początki bibliologii, Warszawa 1989). Z kolei historycznymi i teoretycznymi zagadnieniami bibliotekoznawstwa zajmowała się Zofia Gaca-Dąbrowska. Obok pierwszej tego typu syntezy dotyczącej dwudziestolecia międzywojennego, pt. Bibliotekarstwo II Rzeczypospolitej. Zarys problemów organizacyjnych i badawczych (Wrocław 1983), ogłosiła wiele artykułów poświęconych nauce o bibliotece.

Innym obszarem bibliologii intensywnie rozwijanym w środowisku wrocławskim były badania nad historią i współczesnością czytelnictwa, ze szczególnym uwzględnieniem kultury czytelniczej i medialnej (m.in. K. Głombiowski, Problemy historii czytelnictwa, Wrocław 1966). W późniejszych latach podejmowanie tej tematyki było przede wszystkim zasługą Jadwigi Andrzejewskiej, która wniosła również duży wkład w rozwój badań nad problematyką bibliotek szkolnych i pedagogicznych oraz zawodem nauczyciela-bibliotekarza (Kultura czytelnicza jednostki jako program edukacji czytelniczej i przedmiot badań, „Studia o Książce" 1989).

49 E. HERDEN, B. KOREDCZUK, op. cit., s. 181-200. 
Ważną częścią dokonań naukowych wrocławskiego Instytutu było poszerzanie pola badawczego bibliologii przez podejmowanie badań interdyscyplinarnych. $\mathrm{Na}$ pograniczu bibliologii, naukoznawstwa i historii nauki lokowały się zrealizowane w latach 70. i 80. opracowania K. Migonia i A. Żbikowskiej-Migoń (Książka naukowa w kulturze polskiego Oświecenia, Wrocław 1977). Za pionierskie można uznać badania z pogranicza bibliologii, historii sztuki i sztuk wizualnych zainicjowane przez Małgorzatę Komzę w końcu lat 70. i nadal rozwijane twórczo na przełomie wieków (m.in. Mickiewicz ilustrowany, Wrocław 1987; oraz Żywe obrazy. Między scena, obrazem i ksiązka, Wrocław 1995). Wrocławski Instytut, kontynuując badania rozpoczęte w latach 80 ., stał się też na przełomie wieków, za sprawą licznych konferencji i publikacji, centrum badawczym z zakresu edytorstwa i sztuki książki (m.in. Janusz Sowiński, Typografia wytworna w Polsce 1918-1939, Wrocław 1995; idem, Polskie drukarstwo. Historia drukowania typograficznego i sztuki typograficznej w Polsce w latach 1473-1939, Wrocław 1996).

Przemiany ustrojowe oraz ich konsekwencje cywilizacyjne i kulturowe nie pozostały również bez wpływu na działalność IINiB Uniwersytetu Wrocławskiego. Dominujące w poprzednich latach nurty historyczny i teoretyczny z zakresu bibliologii, prasoznawstwa i bibliotekoznawstwa (kontynuowane m.in. przez Bożenę Koredczuk i Małgorzatę Derkacz), a także bibliotekarstwa szkolnego (głównie dzięki pracom Bogumiły Staniów), były i nadal są ważną częścią prowadzonych w Instytucie badań (chociaż uwzględniających zmiany w otaczającej rzeczywistości), lecz jednocześnie przedstawiciele młodego pokolenia pracowników nauki podejmują badania porównawcze związane z teorią i semiotyką książki tradycyjnej i elektronicznej. Na przełomie wieków powstało wiele opracowań poświęconych komputeryzacji bibliotek, bibliotekom cyfrowym, książce elektronicznej czy społecznościom wirtualnym (autorstwa m.in. Małgorzaty Góralskiej i Anety Firlej-Buzon). Nowym zjawiskiem były też zainicjowane w Instytucie badania z pogranicza bibliografii, bibliologii, informacji naukowej i naukoznawstwa wskazujące na możliwość zastosowania metod ilościowych do interpretacji zjawisk bibliologicznych (m.in. Marta Skalska-Zlat, Bibliografia w Polsce 19451996. Naukoznawcza analiza dyscypliny, Wrocław 2002, kontynuowane obecnie m.in. przez Dorotę Siwecką). Powiększa się też wreszcie grono badaczy podejmujących problematykę książki dla dzieci i młodzieży oraz kontynuujących nurt badań z zakresu sztuki książki (m.in. Elżbieta Jamróz-Stolarska i Ewa Repucho).

\subsubsection{OŚRODEK ŁÓDZKI}

Początki badań księgoznawczych na Uniwersytecie Łódzkim były, jak wspomniano wcześniej, zasługą J. Muszkowskiego. Spośród pracujących z nim asystentów pewien wkład do rozwoju nauki o książce wniosła wówczas Aniela Mikucka. Jako jedna z pierwszych wśród polskich bibliologów podjęła, rozpoczęte jeszcze przed wojną pod kierunkiem J. Muszkowskiego, badania z zakresu czytelnictwa 
(m.in. O metodach badania czytelnictwa, [w:] Badanie czytelnictwa, Warszawa $1948)^{50}$.

Po śmierci Muszkowskiego kontynuacja badań bibliologicznych stała się przede wszystkim udziałem Heleny Więckowskiej. Będąc wprawdzie historykiem z wykształcenia, przyczyniła się jednak do opracowania powojennych dziejów polskiej bibliologii ${ }^{51}$, chociaż nauka o książce nie była dla niej jedynie przedmiotem badań historycznych. W jej poglądach na charakter i znaczenie bibliologii dominował pragmatyzm. Podkreślała, że bibliologia winna być niezbędną podstawą praktyki bibliotekarskiej, jak również kształcenia bibliotekarzy na poziomie akademickim, któremu to zagadnieniu również poświęciła wiele prac (m.in. Uniwersyteckie szkolnictwo bibliotekarskie w Stanach Zjednoczonych, Warszawa 1958 oraz Akademickie ksztatcenie bibliotekarzy, Warszawa 1979). Usamodzielniające się natomiast w latach 60. i 70. bibliotekoznawstwo definiowała jako jeden z działów nauki o książce. Lapidarnie, lecz niezwykle trafnie postawę naukową H. Więckowskiej scharakteryzował K. Migoń, pisząc o niej „bibliolog-praktyk”,52.

Charakter pragmatyczny miały również zainteresowania badawcze następcy H. Więckowskiej na stanowisku kierownika Katedry — Bolesława Świderskiego. W jego dorobku naukowym znalazły się znaczące opracowania dotyczące klasyfikacji piśmiennictwa, katalogów rzeczowych oraz specjalizacji i współpracy w zakresie gromadzenia zbiorów (m.in. Klasyfikacja piśmiennictwa. Katalog rzeczowy, [w:] Bibliotekarstwo naukowe. Z uwzględnieniem dokumentacji naukowo-technicznej, Warszawa 1956; Projekt planu wspótpracy i specjalizacji polskich bibliotek naukowych $w$ zakresie gromadzenia zbiorów, Warszawa 1965) ${ }^{53}$. Niemal wyłącznie do tego nurtu badań ograniczyły się w latach 60. i 70. XX wieku osiągnięcia naukowe ośrodka łódzkiego, i dopiero z czasem, od lat 80., pojawiły się nowe obszary badawcze. Przedmiotem zainteresowania Janusza Dunina stały się problematyka książki tandetnej, zagadnienia edytorstwa i morfologii książki oraz historia bibliofilstwa (m.in. Rozwój cech wydawniczych polskiej książki literackiej XIX-XX wieku, Łódź 1982 i wspólnie z żoną Cecylią Philobiblon polski, Wrocław 1983). Wiele prac z zakresu historii drukarstwa opublikowała Hanna Tadeusiewicz (m.in. Drukarstwo polskie drugiej połowy XIX wieku w świetle fachowych czasopism drukarzy z lat 1872-1900. Problematyka zawodowa i spolecz-

${ }^{50}$ Rozprawy doktorskiej na temat upodobań czytelniczych nie zdążyła ukończyć, zmarła w 1950 roku.

51 H. WIĘCKOWSKA, Organizacja i kierunki badań..., s. 45-77.

52 K. MIGOŃ, Helena Więckowska bibliolog-praktyk, [w:] Helena Więckowska 1897-1984. Red. Jerzy Andrzejewski, Łódź: Wydaw. Uniwersytetu Łódzkiego 1988, s. $29-42$.

53 Zob. Jan JANIAK, Wspótpraca i specjalizacja bibliotek w koncepcji Bolestawa Świderskiego, [w:] Bibliotekarstwo wedtug Bolesława Świderskiego — myśl, praktyka, dydaktyka. Księga pamiątkowa pod red. Stanisławy Kurek-Kokocińskiej, Łódź: Łódzkie Towarzystwo Naukowe 2009, s. 77-111. 
na, Łódź 1982). Tematykę historyczną podejmował też w swoich pracach Jerzy Włodarczyk, szczególnie dużo uwagi poświęcając zagadnieniu formowania się zawodu bibliotekarskiego (m.in. Ksztaltowanie się zawodu bibliotekarskiego na ziemiach polskich w okresie zaborów, Łódź 1990).

Osobnym nurtem badań bibliologicznych realizowanych w Łodzi była tematyka regionalna, w czym specjalizowali się młodsi pracownicy nauki, którzy w latach 80. zdobywali pierwsze stopnie naukowe. Prace te dotyczyły głównie Łodzi (m.in. Jadwiga Konieczna, Dzieje bibliotek tódzkich w latach 1890-1918, Łódź 1983 oraz Maria Majzner, Ruch bibliofilski w Łodzi do 1981 roku, Łódź 1988), a ponadto Tomaszowa Mazowieckiego i Piotrkowa Trybunalskiego (m.in. Magdalena Kwiatkowska, Historia bibliotek w Piotrkowie Trybunalskim w latach 1793 1918, Łódź 1989). Dokumentowano także dzieje kształtowania się sieci ośrodków informacji naukowej, technicznej i ekonomicznej w Łodzi (prace Stanisławy Kurek-Kokocińskiej i Aleksandry Wejman-Sowińskiej).

$\mathrm{W}$ następnych latach, mimo problemów organizacyjnych związanych z brakiem wystarczającej liczby samodzielnych pracowników nauki, kontynuowane i twórczo rozwijane były badania dotyczące dziejów książki w Łodzi i regionie (także w Wielkopolsce, czym zajmowały się m.in. Ewa Andrysiak i Agata Walczak-Niewiadomska), przy czym interesujące wyniki dało przyjęcie jako centralnej kategorii badawczej pojęcia „kultura książki” (J. Konieczna, Kultura książki polskiej w Łodzi przemysłowej (1820-1918), Łódź 2005). Jednocześnie przedmiotem analizy czyniono rozwój współczesnych instytucji książki w Łodzi — bibliotek i wydawnictw (prace Magdaleny Rzadkowolskiej i J. Koniecznej). W nurcie historycznym lokują się także badania nad książką rękopiśmienną Andrzeja Wałkówskiego oraz edytorstwem naukowym w XIX wieku w zaborze rosyjskim M. Kwiatkowskiej. Nowym obszarem badawczym, poczynając od lat 90., stały się problemy książki, czytelnictwa oraz bibliotek dla dzieci i młodzieży, zarówno w aspekcie historycznym, jak i współczesnym (zajmowali i zajmują się tym J. Konieczna, Alina Brzuska-Kępa, Alicja Mazan-Mazurkiewicz, A. Walczak-Niewiadomska) Kontynuowane i rozwijane były badania prasoznawcze, zwłaszcza dotyczące rynku prasowego (Ewelina Kristanova, Magdalena Przybysz-Stawska), a także studia z zakresu morfologii książki i czytelnictwa, również kultury czytelniczej dzieci i młodzieży (Jacek Ladorucki, M. Rzadkowolska, Mariola Antczak). W ostatnim dziesięcioleciu przedmiotem badań stała się (również przy współpracy z Biblioteką Uniwersytecką) spuścizna i dokonania poprzedników - Jana Muszkowskiego, Heleny Więckowskiej i Janusza Dunina. Obok nurtu historycznego i regionalnego, podobnie jak w innych ośrodkach, podejmowano i rozwijano zagadnienia z obszaru szeroko pojętej informacji naukowej, a obecnie informatologii, książki elektronicznej i bibliotek cyfrowych (S. Kurek-Kokocińska, Grzegorz Czapnik). Dużym osiągnięciem Katedry było też opracowanie Podręcznego stownika bibliotekarza (Warszawa 2011). 
Na koniec tego krótkiego przeglądu badań naukowych realizowanych w tych trzech ośrodkach akademickich należy dodać, że wspólnym ich osiągnięciem były zrealizowane w latach 70. przy współpracy pracowników bibliotek naukowych trzy duże prace o charakterze encyklopedycznym: Encyklopedii wiedzy o ksiązce (pod red. A. Birkenmajera, B. Kocowskiego i J. Trzynadlowskiego, Wrocław 1971), Encyklopedii wspótczesnego bibliotekarstwa polskiego (pod red. K. Głombiowskiego, B. Świderskiego, H. Więckowskiej, Wrocław 1976) oraz Słownika pracowników książki polskiej (pod red. Ireny Treichel, Łódź 1972). Ten ostatni słownik, redagowany przez ośrodek łódzki (kolejni redaktorzy to H. Tadeusiewicz i M. Rzadkowolska), w sukcesywnie wydawanych Suplementach (1-4) ukazuje się do dzisiaj.

\subsubsection{OŚRODKI KRAKOWSKI, KATOWICKI I LUBELSKI}

W pozostałych ośrodkach, które w większości rozpoczynały działalność w początkach lub w połowie lat 70., kierunki i charakter podejmowanych badań naukowych uzależnione były od proweniencji naukowej kierowników poszczególnych jednostek, którzy - jak już wspomniano — byli zazwyczaj absolwentami innych dyscyplin humanistycznych (filolodzy, historycy). W tej sytuacji, w drugiej połowie lat 70., w nowych ośrodkach podejmowano badania z zakresu literaturoznawstwa, często z uwzględnieniem nurtu regionalnego, dotyczące miejsca i roli książki w kulturze w minionych wiekach, a także lokalnego czasopiśmiennictwa oraz ludzi i instytucji książki ${ }^{54}$. Z czasem wraz ze stabilizacją formalnoorganizacyjną niektórych ośrodków i budowaniem własnej kadry naukowo-dydaktycznej kształtowały się warunki do rozwoju badań z obszaru szeroko pojętej bibliologii i wytwarzaniu się określonych specjalizacji kierunkowych w tych badaniach.

Przykładem może być Wyższa Szkoła Pedagogiczna w Krakowie, gdzie na kształtowanie się kierunków badań naukowych duży wpływ wywarły rozległe zainteresowania naukowe Jerzego Jarowieckiego, który w swoich badaniach podejmował problematykę historycznoliteracką, prasoznawczą, lecz wiele uwagi poświęcał też kwestiom funkcjonowania bibliotek szkolnych (m.in. Konspiracyjna prasa w Krakowie w latach okupacji hitlerowskiej 1939-1945, Kraków 1980; Literatura i prasa w latach okupacji hitlerowskiej, Kraków 1983). Ważnym nurtem naukowym, realizowanym tam głównie za sprawą profesor Wacławy Szelińskiej, były też badania nad rolą i znaczeniem książki w życiu naukowym i umysłowym Krakowa w XV i XVI wieku (Biblioteki profesorów Uniwersytetu Krakowskiego w XV i początkach XVI wieku, Kraków 1966 oraz Rola książki w życiu umystowym Polski w XV wieku, Kraków 1974).

Opracowania z zakresu historii książki, bibliotek, dziejów ruchu wydawniczego, księgarstwa i prasoznawstwa stanowią też znaczącą część dorobku nauko-

54 Informacje o poszczególnych placówkach na podstawie dotyczących ich opracowań cytowanych wcześniej w niniejszej pracy. 
wego pracowników tego Instytutu w okresie ostatnich 25 lat. Przedmiotem badań o charakterze historycznym są przede wszystkim instytucje książki w Krakowie i w Galicji (prace Jana Bujaka, Marii Konopki, Marka Pieczonki, Adama Ruty, Iwony Pietrzkiewicz, Józefa Szockiego), lecz także w innych regionach Polski (Barbary Góry, Lilii Kowkiel). Natomiast stosunkowo mało jeszcze popularne na gruncie bibliologii badania z zakresu antropologii książki są udziałem Andrzeja Dróżdża. Kontynuowane są zapoczątkowane przez J. Jarowieckiego badania prasoznawcze. Obejmują one prasę krakowską, lwowską, a także inne polskie periodyki, głównie publikowane w XX wieku, czym zajmowali się i zajmują m.in. Władysław Marek Kolasa, Urszula Lisowska-Kożuch, Krzysztof Woźniakowski, Grażyna Wrona, Grzegorz Nieć, Michał Rogoż. Ze względu na charakter uczelni nadal prowadzone są badania dotyczące bibliotekarstwa szkolnego, biblioterapii, czytelnictwa oraz metodyki pracy bibliotecznej (Halina Kosętka, Lidia Ippoldt, Iwona Pietrzkiewicz). Specyfika Uniwersytetu Pedagogicznego wymaga także istnienia obszaru badań interdyscyplinarnych. W ostatnich latach dotyczyły one głównie historii oraz dziejów i teorii literatury (prace Michała Zięby, W. Szelińskiej, H. Kosętki, Marii Jazowskiej-Gumulskiej).

Instytut ma również znaczące osiągnięcia $\mathrm{w}$ rozwijaniu nauki o informacji. Podejmowane są badania dotyczące kultury i edukacji informacyjnej oraz potrzeb użytkowników informacji. Jednocześnie przedmiotem zainteresowań są kwestie bibliotek cyfrowych i digitalizacji dokumentów (Hanna Batorowska, Barbara Kamińska-Czubała, Stanisław Skórka). Efektem wieloaspektowych badań z dziedziny informacji naukowej prowadzonych w IINiB Uniwersytetu Pedagogicznego są także podręczniki akademickie z tego zakresu (m.in. Wybrane zagadnienia nauki o informacji i technologii informacyjnej, wyd. 1996 i 2000) ${ }^{55}$.

Również w Zakładzie Bibliotekoznawstwa i Informacji Naukowej Uniwersytetu Śląskiego w pierwszych latach działalności dominowała w badaniach tematyka literaturoznawcza $\mathrm{z}$ uwzględnieniem nurtu regionalnego. W miarę zatrudniania absolwentów własnych studiów, a jednocześnie pozyskiwania bibliotekarzy praktyków z dorobkiem naukowym, obszar podejmowanych badań poszerzał się o problemy bibliotekoznawcze, a także zagadnienia z pogranicza informacji naukowej i bibliotekarstwa praktycznego (Zbigniew Żmigrodzki, Nowoczesność $w$ bibliotece, Katowice 1979; idem, Racjonalizacja pracy bibliotecznej. Problemy, kierunki, metody, Katowice 1986; Jacek Ratajewski, Biblioteki naukowe i fachowe oraz ośrodki informacji naukowo-technicznej w komunikacji społecznej, Katowice 1982). W latach 80. we współpracy z ośrodkami w Opolu i Wrocławiu realizowano szeroko zakrojone badania nad dziejami polskiej książki na Śląsku w XIX i XX wieku, co zaowocowało w następnej dekadzie wielotomowym wydawnictwem zbiorowym pod redakcją najpierw Adama Jarosza, a później Marii

55 H. GRZYWACZ, A. RUTA, op. cit., s. 120-144; http://iinib.up.krakow.pl/badania-naukowe.html?1_4 [dostęp: 29 VII 2016]. 
Pawłowiczowej. Sytuacji książki polskiej w okresie zaborów dotyczą też prace Elżbiety Gondek (m.in. Polska książka literacka na Ślasku pod panowaniem pruskim 1795-1863, Katowice 1995 i Rynek ksiażki na Ślasku pod panowaniem pruskim w XIX wieku. Drukarnie, księgarnie, płatne wypożyczalnie publikacji, Katowice $2001)^{56}$.

Poczynając od lat 80., swoistą specjalizacją Instytutu stały się zagadnienia ochrony i konserwacji zbiorów bibliotecznych. Dzięki współpracy, a później zatrudnieniu specjalistów z innych dziedzin wiedzy, takich jak Leonard Ogierman i Bronisław Zyska, udawało się łączyć teorię (m.in. B. Zyska, Ochrona zbiorów bibliotecznych przed zniszczeniem, t. 1-4, Katowice 1991-1998) z praktyczną działalnością na rzecz renowacji zagrożonych wydawnictw. W latach 90. zapoczątkowane zostały w INBiIN Uniwersytetu Śląskiego badania nad książką i czytelnictwem młodych odbiorców, obejmujące z czasem wielorakie aspekty współczesnej książki dziecięco-młodzieżowej (m.in. Irena Socha, „Przykładne, użyteczne i zabawne”. O polskich ksiażkach dla młodego odbiorcy na Ślasku $w$ drugiej połowie XIX i na poczatku XX wieku, Katowice 2001). Znaczący jest też w badaniach nad książką dziecięcą udział Krystyny Heskiej-Kwaśniewicz, zwłaszcza jako inicjatorki i redaktorki czterotomowej publikacji Literatura dla dzieci i młodzieży (po roku 1980) (Katowice 2008-2014). Istotnym wkładem śląskiego środowiska w rozwój polskiej bibliologii było opracowanie podstawowych syntez wiedzy niezbędnych w dydaktyce akademickiej — podręczników: Bibliotekarstwo pod red. Z. Żmigrodzkiego (Warszawa 1994, 1998), Bibliografia. Metodyka i organizacja (Warszawa 2000) i Bibliotekarstwo pod red. Anny Tokarskiej (Warszawa 2013).

Generalnie w działalności naukowo-badawczej IBiIN Uniwersytetu Śląskiego można wyraźnie wyróżnić dwa główne nurty badawcze: dzieje książki, prasy, bibliotek i czytelnictwa na ziemiach polskich oraz współczesne bibliotekarstwo polskie i europejskie, a także problemy informacji naukowej. Pierwszy nurt obejmuje m.in. badania z zakresu kultury książki na Śląsku (prace Danuty Sieradzkiej, A. Tokarskiej, Małgorzaty Gwadery), lecz także w środowiskach mniejszości narodowych, na kresach dawnej Polski (prace Jerzego Reizesa-Dzieduszyckiego), historię prasy i w dalszym ciągu zagadnienia czytelnictwa oraz książki i prasy dla młodego odbiorcy (prace I. Sochy i Katarzyny Tałuć), w aspekcie historycznym i współczesnym. Natomiast w ramach drugiego nurtu podejmowane są badania związane z kierunkami rozwoju informatologii, funkcjonowaniem bibliotecznych systemów informacyjnych, specjalistycznych narzędzi sieciowych archiwów i instytucji kultury (prace Diany Pietruch-Reizes i Jacka Tomaszczyka), a także dotyczące jakości usług bibliotecznych oraz efektywnego wykorzystania

56 E. GONDEK et al., op. cit., s. 50-56. 
narzędzi marketingowych w kontaktach bibliotekarz-interesariusz (prace Beaty Żołędowskiej-Król i Ireny Sochy) ${ }^{57}$.

Na Uniwersytecie Jagiellońskim, gdzie, jak wspomniano wcześniej, przyjęto tzw. matematyczno-społeczny model kształcenia, głównie za sprawą Wandy Pindlowej rozwijał się nurt badań oraz rozważań teoretycznych i metodologicznych związanych z kształtowaniem się stosunkowo nowej jeszcze dyscypliny, jaką była informacja naukowa (m.in. W. Pindlowa, Kształcenie studentów jako użytkowników informacji naukowej: z pogranicza informatologii i pedagogiki, Kraków 1984). Jednocześnie ważne miejsce w działalności naukowej ówczesnego Zakładu zajmowała problematyka historyczna, reprezentowana choćby przez badania nad kulturą książki w Krakowie w XVIII-XIX wieku (m.in. Maria Kocójowa, Krakowski świat książki doby autonomii galicyjskiej (ksztaltowanie nowego modelu w latach 1867-1882), Kraków 1990; Krystyna Bednarska-Ruszajowa, Od Homera do Jana Jakuba Rousseau. W kręgu lektur profesorów krakowskich okresu Oświecenia, Kraków 1991) czy dziejów drukarstwa (m.in. Jan Pirożyński, Johannes Gutenberg i poczatki ery druku, Warszawa 2002), chociaż stopniowo była spychana na drugi plan. Natomiast w latach 80. i 90. XX wieku, głównie dzięki Jackowi Wojciechowskiemu — wieloletniemu dyrektorowi Wojewódzkiej Biblioteki Publicznej w Krakowie, obszar prowadzonych badań poszerzał się o problemy współczesnego bibliotekarstwa i czytelnictwa (m.in. jego prace Czytelnictwo, Kraków 1985 oraz Marketing w bibliotece, Kraków 1993). Problematyka ta została następnie rozszerzona o kolejne aspekty współczesnego bibliotekarstwa i innych instytucji książki, zwłaszcza obecnych w Internecie ${ }^{58}$.

Z czasem prace z zakresu nauki o informacji, bibliometrii czy bibliografii zaczęły przeważać w dorobku tego Instytutu (np. Maria Próchnicka, Informacja a umyst, Kraków 1991). Szczególnym przedmiotem zainteresowań naukowych są obecnie problemy zarządzania informacją i wiedzą, zwłaszcza upublicznianą w ramach bibliotek cyfrowych, czym zajmują się m.in. Wiesław Babik, D. Pietruch-Reizes i Marek Nahotko. Inne zagadnienia z obszaru szeroko pojętej informacji naukowej realizowane w krakowskim Instytucie to kwestie kultury informacyjnej oraz kompetencji i zachowań informacyjnych (m.in. prace Agnieszki Korycińskiej-Huras). Podejmowane są także badania dotyczące systemów informacji, czasopism elektronicznych (M. Próchnicka, M. Nahotko i Małgorzata Janiak), lecz także filozofii oraz podstaw teoretycznych i metodologicznych bibliologii i informatologii (Remigiusz Sapa, Sabina Cisek). Wśród dokonań naukowych pracowników są też zagadnienia nowatorskie, np. ekologia informacji (W. Babik).

57 Ibidem, s. 47-65; kwerendy katalogów bibliotecznych.

58 Remigiusz SAPA, Przemiany i perspektywy. Instytut Informacji Naukowej i Bibliotekoznawstwa Uniwersytetu Jagiellońskiego w Krakowie, Forum Bibliotek Medycznych 2014, nr 1 (13), s. 35-54; Biblioteka i informacja w komunikowaniu. Pod red. Marii Kocójowej, Kraków 2000 (Zeszyty Naukowe Uniwersytetu Jagiellońskiego, nr 1243); http://www.inib.uj.edu.pl/konferencje-iinib-uj [dostęp: 20 VIII 2016]; http://www.inib.uj.edu.pl/bibliografia-iinib-uj [dostęp: 20 VIII 2016]. 
Niezależnie od dominacji zagadnień informacyjnych nadal w obszarze zainteresowań części pracowników obecna jest problematyka dotycząca roli książki w komunikacji społecznej, książki i bibliotek w utworach literackich, a także książek dla dzieci (prace Anny Grucy, Zdzisława Pietrzyka i Piotra Lechowskiego).

Natomiast $\mathrm{w}$ badaniach prowadzonych $\mathrm{w}$ ośrodku bibliotekoznawczym Uniwersytetu Marii Curie-Skłodowskiej zdecydowanie przeważał nurt historyczny, o czym zdecydowały wieloletnie jego związki z tamtejszym Instytutem Historii i osoba ówczesnego kierownika - Józefa Szymańskiego, autora m.in. kilkakrotnie wznawianego od początku lat 70. podręcznika Nauki pomocnicze historii. Historykiem był również Antoni Krawczyk, a w jego dorobku znalazło się m.in. wiele artykułów poświęconych dziejom książki w Lublinie. Instytucje książki w Lublinie w XIX wieku były też przedmiotem zainteresowania Mieczysławy Wełny-Adrianek, chociaż jej prowadzone w latach 70. badania dotyczyły przede wszystkim podręczników i bibliotek szkolnych w zaborze rosyjskim w XIX wieku, czego efektem były liczne artykuły. Natomiast historia drukarstwa w Polsce w okresie staropolskim była przedmiotem zainteresowania Marii Judy (m.in. Przywileje drukarskie w Polsce, Lublin 1992).

W prowadzonych obecnie badaniach nadal ważne miejsce zajmuje ujęcie historyczne, lecz nie jest ono już dominujące. Najnowsze opracowania o charakterze historycznym dotyczą dziejów książki i kultury piśmienniczej na ziemiach polskich od średniowiecza po wiek XVIII oraz dziejów kultury w ciągu wieków (do współczesności - prace M. Judy i Piotra Tafiłowskiego), natomiast społecznych uwarunkowań książki w wieku XIX dotyczą badania Anny Dymmel. Ważne miejsce zajmuje także historia, teoria i metodyka polskich bibliografii (prace Jarosława Packa i Alicji Matczuk). Jednocześnie rozwijane są badania dotyczące współczesnego rynku książki i mediów adresowanych do młodego odbiorcy, kultury czytelniczej oraz miejsca książki i innych mediów w komunikacji społecznej. Ważnym obszarem badawczym stały się również współczesne zmiany kulturowe i determinanty tych zmian, a także rola książki i bibliotek w systemie kultury, czym zajmowały się i zajmują m.in. Anita Has-Tokarz, Renata Malesa i Bożena Rejakowa.

W ostatnich latach w prowadzonych w Instytucie badaniach coraz bardziej widoczne jest jednak zainteresowanie zagadnieniami z zakresu szeroko pojętej informacji naukowej, co wiąże się też zapewne z prowadzeniem nowego kierunku studiów - informacja w e-społeczeństwie. Podejmowane są prace z zakresu zarządzania informacją, dotyczące teorii i wykorzystania języków informacyjno-wyszukiwawczych, przetwarzania języka naturalnego, a także zastosowania technologii komputerowych i teleinformatycznych (m.in. Zbigniew Osiński i Sebastian Kotuła) ${ }^{59}$.

59 Anita HAS-TOKARZ, Renata MALESA, Instytut Bibliotekoznawstwa i Informacji Naukowej Uniwersytetu Marii Curie-Skłodowskiej w Lublinie - z perspektywy dziesięciu lat istnie- 


\subsection{OŚRODKI TORUŃSKI, KIELECKI I BYDGOSKI}

Podobnie jak w innych ośrodkach badania naukowe prowadzone na Uniwersytecie Mikołaja Kopernika w Toruniu objęły problemy szeroko pojętej bibliologii w aspekcie zarówno historycznym, jak i współczesnym, informacji naukowej oraz bibliotekarstwa, czytelnictwa i biblioterapii. Badania historyczne dominowały w pierwszym dwudziestoleciu istnienia toruńskiego ośrodka bibliotekoznawczego. Obejmowały wówczas takie zagadnienia, jak inkunabulistyka, historia drukarstwa, ruchu wydawniczo-księgarskiego czy bibliofilstwa. Szczególnie dużo uwagi poświęcano dziejom książki na terenie Prus Królewskich i Książęcych (m.in. Bronisława Woźniczka-Paruzel, Polski ruch wydawniczy w Prusach Zachodnich 1848-1914. Próba syntezy, Toruń 1993; Janusz Tondel, Srebrna Biblioteka księcia Albrechta Pruskiego i jego żony Anny Marii, Toruń 1994; Iwona Imańska, Obieg książki w Prusach Królewskich w XVIII wieku, Toruń 1993). Nurt historyczny nadal jest obecny w prowadzonych w Instytucie badaniach naukowych, chociaż poszerzony o zagadnienia ruchu wydawniczo-księgarskiego od XVIII wieku po współczesność (I. Imańska, Wanda Ciszewska) oraz problematykę introligatorstwa europejskiego i sztukę exlibrisu XV-XXI wieku (Arkadiusz Wagner). Ważną częścią dokonań naukowych toruńskiego Instytutu Informacji Naukowej i Bibliologii są rozbudowane badania prasoznawcze poszerzone o zagadnienia cenzury i prawa prasowego. Obok tematyki historycznej (realizowanej przez Grażynę Gzellę i Jacka Gzellę) przedmiotem zainteresowań jest prasa lokalna oraz czasopiśmiennictwo naukowe i popularnonaukowe (prace Barbary Centek i Doroty Degen). Swoistym wyróżnikiem Instytutu jest realizowany od lat nurt biblioterapeutyczny związany z pracą w środowiskach osób z rozmaitymi niepełnosprawnościami, wśród seniorów, lecz także wśród dzieci (prace Bronisławy Woźniczki-Paruzel i Małgorzaty Fedorowicz-Kruszewskiej). Różnorodna jest też problematyka badań z zakresu informacji naukowej. Między innymi podejmowane są takie zagadnienia, jak zarządzanie informacją i wiedzą, architektura informacji, ocena jakości zasobów informacji, digitalizacja oraz tworzenie elektronicznych zasobów informacji. Dużo uwagi poświęca się również problemom kształcenia użytkowników informacji, a szczególnie koncepcji information literacy, czym zajmują się m.in. Ewa Głowacka, Małgorzata Kowalska i Natalia Pamuła-Cieślak ${ }^{60}$.

Bezpośredni wpływ na kierunki badań naukowych Instytutu Bibliotekoznawstwa i Dziennikarstwa na Uniwersytecie Jana Kochanowskiego ma jego sytuacja organizacyjna i kierunki realizowanych studiów. W latach 80 . i w początkach lat

nia, Forum Bibliotek Medycznych 2013, nr 2 (12), s. 145-159, http://www.umcs.pl/pl/publikacje-ksiazkowe,7302.htm\#page-1 [dostęp: 21 VIII 2016].

${ }^{60}$ Małgorzata KOWALSKA, Wanda A. CISZEWSKA, Instytut Informacji Naukowej i Bibliologii Uniwersytetu Mikołaja Kopernika w Toruniu — historia i współczesność, Forum Bibliotek Medycznych 2014, nr 1 (13), s. 55-82, http://www.inibi.umk.pl/index.php?option=com_conten t\&view=article\&id=6\&Itemid=11 [dostęp: 31 VIII 2016]. 
90. badania pracowników dotyczyły głównie dziejów książki i bibliotek w XIX i XX wieku, ze szczególnym uwzględnieniem Kielecczyzny, (m.in. Adam Massalski, Szkolnictwo średnie Kielc do roku 1862, Kielce 1983; Mieczysław Adamczyk, Prasa Kielecczyzny — tradycje i współczesność, Kielce 1987; Czesław Erber, Dzieje książki na Kielecczyźnie w latach 1795-1865, Kielce 1996), chociaż niejednokrotnie wykraczano poza wąski regionalizm (m.in. Danuta Adamczyk, Instytucje wydawnicze Polskiej Partii Socjalistycznej 1892/93-1948, Kraków 1997 i liczne prace Danuty Hombek dotyczące prasy polskiej w XVIII wieku). W pierwszej dekadzie XXI wieku coraz częściej natomiast podejmowano zagadnienia z zakresu prasoznawstwa (prace Jolanty Chwastyk-Kowalczyk i Tomasza Chrząstka), medioznawstwa (prace Tomasza Mielczarka, Barbary Leny Gierszewskiej, Jolanty Dzierżyńskej-Mielczarek) oraz edytorstwa i księgarstwa (prace D. Adamczyk, Oskara Stanisława Czarnika, Moniki Olczak-Kardas i Aleksandry Lubczyńskiej) zarówno w ujęciu historycznym, jak i współczesnym. Nadal podejmowane są także zagadnienia mieszczące się w obszarze tradycyjnej bibliologii i bibliotekoznawstwa takie, jak społeczna funkcja książki czy dzieje bibliotek (prace Stanisława Adama Kondka, Jolanty Dzieniakowskiej, Izabeli Krasińskiej i Marii Siudy) ${ }^{61}$.

Głównym obszarem zainteresowań pracowników ośrodka bydgoskiego były i są zagadnienia dotyczące historii książki, bibliotek, drukarstwa i czasopism regionu bydgoskiego, Kujaw i Pomorza Nadwiślańskiego (Franciszek Mincer, Zdzisław Kropidłowski, Bernadeta Iwańska-Cieślik). W kręgu zainteresowań bydgoskich bibliologów pozostaje również historia książki w staroży tności, także w epoce nowożytnej, a szczególnie dzieje bibliotek kościelnych (Dariusz Spychała, Z. Kropidłowski). Tematyka historyczna poszerzana jest również o zagadnienia współczesnego bibliotekarstwa, szczególnie ochrony zbiorów (Ryszard Nowicki), oraz czytelnictwa (Katarzyna Domańska, Katarzyna Wodniak) i introligatorstwa

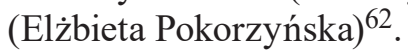

Swój udział w rozwoju polskiej bibliologii ma też Zakład Informacji Naukowej i Bibliotekoznawstwa na Uniwersytecie w Białymstoku. Są to głównie badania regionalne dotyczące czytelnictwa, bibliotek i prasy na Podlasiu (prace Katarzyny Zimnoch, Katarzyny Sawickiej-Mierzyńskiej, Anny Nosek). Równocześnie jednak, kontynuując tradycję zapoczątkowaną przez A. Sitarską, nadal podejmowano zagadnienia z zakresu informatologii - języków i systemów informacyjno-wyszukiwawczych oraz bibliografii (prace Jadwigi Sadowskiej). W obszarze prowadzonych $\mathrm{w}$ Białymstoku badań znalazły się też problemy książki i literatury dla dzieci i młodzieży (Anna Nosek).

Godny zauważenia jest też niewątpliwie wkład, jaki w rozwój nauki o książce i poszerzanie jej obszarów badawczych wnosi niewielki Zakład Archiwistyki, Bibliotekoznawstwa i Informacji Naukowej Uniwersytetu Warmińsko-Mazurskiego

${ }^{61}$ I. KRASIŃSKA, op. cit., s. 66-119.

62 Z. KROPIDŁOWSKI, op. cit., s. 29-46; K. ADAMCZYK, op. cit., s. 29-45. 
w Olsztynie. Jest jedynym w kraju ośrodkiem badania kultury staroobrzędowców i druków cyrylickich (prace Zoi Jaroszewicz-Pieresławcew), a jednocześnie miejscem prowadzenia interesujących prac dotyczących diagnozowania barier informacyjnych, zarządzania zasobami ludzkimi oraz informacją i wiedzą, czym zajmuje się Marzena Świgoń ${ }^{63}$.

Zaprezentowany tu przegląd, zarówno w wymiarze ilościowym jak i merytorycznym, nie pozostawia wątpliwości, że po siedemdziesięciu latach obecności w środowisku uniwersyteckim polska bibliologia, mimo iż przechodziła gorsze i lepsze okresy, jawi się obecnie jako w pełni ukształtowana dyscyplina naukowa. Nie oznacza to jednak jej absolutnej stabilizacji i pewności dalszego rozwoju w obecnym kształcie. Inwazja mediów elektronicznych i zmieniające się formy komunikowania wpływają na strukturę książki i jej funkcje. Bibliologowie stają więc przed nowymi wyzwaniami. Jaka ma być współczesna bibliologia, jakie subdyscypliny mają ją tworzyć, gdzie powinny przebiegać granice między nimi? Są to oczywiście pytania nie tylko do teoretyków nauki o książce. Muszą się z nimi mierzyć także wszyscy uprawiający dyscyplinę. Dokonany przegląd, zwłaszcza za ostatnie 25 lat, wydaje się potwierdzać, że takie poszukiwania trwają.

JADWIGA KONIECZNA

\section{THE CONTRIBUTION OF ACADEMIC LIBRARY SCIENCE TO THE DEVELOPMENT OF BIBLIOLOGY AND INFORMATION SCIENCE IN POLAND IN 1945-2015}

\section{Summary}

The aim of the study is to present the origins and development of academic institutions educating librarians in Poland in 1945-2015, taking into account the institutional and scholarly aspects. In the first part of the paper the author presents the history of various institutions - university faculties, departments and institutes — divided into three chronological periods (1945-1974, 1975-1989, 1990-2015). She takes into account the circumstances surrounding their establishment (including the legal framework), their founders, staff, organisational structures and their changes. In addition, she points to other manifestations of academic life influencing the work of academic library science centres, like conferences and professional journals. In the second part, devoted to a discussion of research into bibliology and information science conducted at Polish universities, the author focuses on the various subjects, treating chronology only as an element organising descriptions of research processes at the various library studies centres. She points to areas of research as well as changes occurring in their subjects in the analysed period, referring to the names of selected scholars and titles of their most important works. Like in part one, she also discusses the social,

$63 \mathrm{http}: / /$ www.uwm.edu.pl/historia/index.php/instytut/zaklady/zakladarchiwistykibibliotekoznawstwaiinformacjinaukowej/informacjenatematzakladuarchiwistyki. 
political and cultural determinants stimulating research processes, paying particular attention to the impact of the new technologies and media. The author's overview confirms the huge role played by academic institutions engaged in library studies in the consolidation of the position of bibliology as an academic discipline, but at the same time shows how the research profile of book science has been changing in recent years, evolving in the direction of phenomena associated with information science and new technologies.

KEY WORDS: bibliology, research, information science, research, academic library science, history 